\title{
From mythology to science: the development of scientific hydrological concepts in Greek antiquity and its relevance to modern hydrology
}

\author{
Demetris Koutsoyiannis and Nikos Mamassis \\ Department of Water Resources and Environmental Engineering, School of Civil Engineering, \\ National Technical University of Athens, Heroon Polytechneiou 5, GR 15780 Zographou, Greece
}

Correspondence: Demetris Koutsoyiannis (dk@itia.ntua.gr)

Received: 4 January 2021 - Discussion started: 12 January 2021

Revised: 30 March 2021 - Accepted: 1 April 2021 - Published: 10 May 2021

\begin{abstract}
Whilst hydrology is a Greek term, it was not in use in the Classical literature, but much later, during the Renaissance, in its Latin form, hydrologia. On the other hand, Greek natural philosophers (or, in modern vocabulary, scientists) created robust knowledge in related scientific areas, to which they gave names such as meteorology, climate and hydraulics. These terms are now in common use internationally. Greek natural philosophers laid the foundation for hydrological concepts and the hydrological cycle in its entirety. Knowledge development was brought about by searches for technological solutions to practical problems as well as by scientific curiosity. While initial explanations belong to the sphere of mythology, the rise of philosophy was accompanied by the quest for scientific descriptions of the phenomena. It appears that the first geophysical problem formulated in scientific terms was the explanation of the flood regime of the Nile, then regarded as a paradox because of the spectacular difference from the river flow regime in Greece, i.e. the fact that the Nile flooding occurs in summer when in most of the Mediterranean the rainfall is very low. While the early attempts were unsuccessful, Aristotle was able to formulate a correct hypothesis, which he tested through what appears to be the first scientific expedition in history, in the transition from the Classical to Hellenistic periods. The Hellenistic period brought advances in all scientific fields including hydrology, an example of which is the definition and measurement of flow discharge by Heron of Alexandria. These confirm the fact that the hydrological cycle was well understood in Ancient Greece, yet it poses the question why correct explanations were not accepted and, instead, why ancient and modern mythical views were preferred up to the 18th century.
\end{abstract}

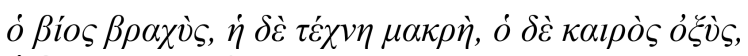
$\dot{\eta} \delta \dot{\varepsilon} \pi \varepsilon \tilde{\imath} \rho \alpha \sigma \varphi \alpha \lambda \varepsilon \rho \dot{\eta}, \dot{\eta} \delta \dot{\varepsilon} \kappa \rho i \sigma \iota \varsigma \chi \alpha \lambda \varepsilon \pi \dot{\eta}$

(Life is short and Art long; the times sharp, experience perilous and judgment difficult.) Hippocrates, Aphorismi, 1.1 (translated by the authors)

\section{歸根得旨}

(To return to the root is to find the meaning) Sengcan, Xinxinming (Verses on the Faith Mind, translated by Richard B. Clarke; https://www.sacred-texts.com/bud/zen/ $\mathrm{fm} / \mathrm{fm} . \mathrm{htm})$

\section{Introduction - Ancient wisdom and its modern perception}

In all ancient civilizations, the causes of natural processes, particularly the geophysical and hydrological, were attributed to supernatural powers, usually deities. Mythological explanations have been very influential in triggering social behaviours, but also in developing human skills, such as imagination and symbolism. In this respect, the rich Ancient Greek mythology has been inspiring in the arts and continues to be so even in modern times. This is illustrated in Fig. 1, depicting the mythological battle of Hercules, the well-known hero, against Achelous, a deity personifying the most important river of Greece. The three panels in the figure represent different arts, different aesthetic styles and different periods: 
6th century BC, 19th century and 20th century, but with influences from the Byzantine tradition.

The myth of the battle of Hercules against Achelous

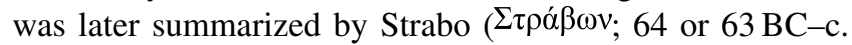
$\mathrm{AD} 24)$, the Greek geographer, as follows:

This gave occasion to a fable, how Hercules overcame the Achelous in fight, and received in marriage as the prize of his victory, Deianeira, daughter of Oeneus. Sophocles introduces her, saying, "My suitor was a river, I mean the Achelous, who demanded me of my father under three forms; one while coming as a bull of perfect form, another time as a spotted writhing serpent, at another with the body of a man and the forehead of a bull." Some writers add, that this was the horn of Amaltheia, which Hercules broke off from the Achelous, and presented to Oeneus as a bridal gift. Others, conjecturing the truth included in this story, say, that Achelous is reported to have resembled a bull, like other rivers, in the roar of their waters, and the bendings of their streams, which they term horns; and a serpent from its length and oblique course; and bull-fronted because it was compared to a bull's head; and that Hercules, who, on other occasions, was disposed to perform acts of kindness for the public benefit, so particularly, when he was desirous of contracting an alliance with Oeneus, performed for him these services; he prevented the river from overflowing its banks, by constructing mounds and by diverting its streams by canals, and by draining a large tract of the Paracheloitis, which had been injured by the river; and this is the horn of Amaltheia. (Strabo, Geography, 10.2.19; English translation by Hans C. Hamilton; see original in the Supplement, $[\mathrm{OT} 1]^{1}$ )

In addition to the myth's summary, in this passage Strabo deciphers the symbolic meaning of the myth: the struggle of humans to control environmental threats and their victory, which is rewarded by the horn of Amaltheia, an eternal symbol of abundance. This deciphering was possible after the revolution that occurred in Greece during the 6th century BC,

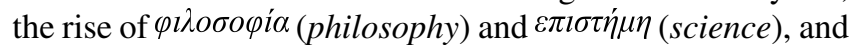
the mobilizing of $\lambda o ́$ 'os (logos, reason) to explain not only the natural phenomena, such as rivers overflowing, but also human actions, such as the creation of myths.

Humans have never been reluctant to create myths, even though their focus may change in different time periods. For example, in our era the dominant mythological element is that humans have replaced deities in ruling the universe and the natural processes (cf. anthropogenic climate change and

\footnotetext{
1 "OT" stands for "original text" and the number that follows facilitates locating the original text (mostly in Greek) in the Supplement, Sect. S4.
}

Anthropocene - or, according to Sagoff, 2018, Narcisscene). Furthermore, in current myth making, heroic feats are not victories in the struggle with nature, but rather the protection of nature from the destructive power of human sinners or demons.

Coming to hydrology, it is notable that Klemeš (1986) used the myth of the Lernean Hydra to express the development of misconceptions in modern hydrology: fighting them has been difficult because, as soon as one of its heads is struck off, two shoot up in its place. Therefore, there is an abundance of such misconceptions, or modern hydrological myths, but here we will refer only to those about the origin and historical development of hydrology per se.

A first characteristic example is the following extract from Price (1996):

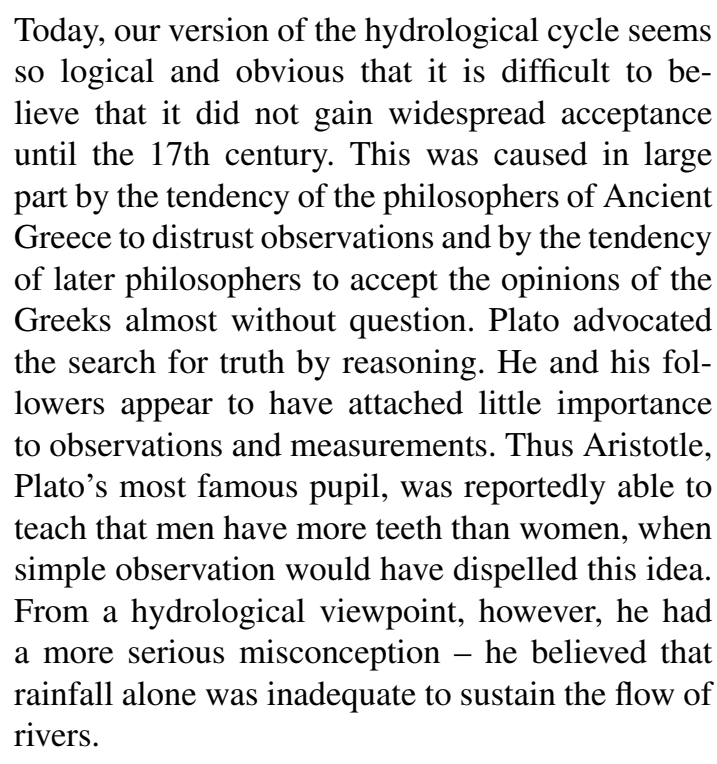

It is true that Plato (Fig. 2) advocated the search for truth by reasoning as he regarded reasoning as an important element distinguishing what is and what is not science (see below) - and we do not have any hesitation in supporting this view of Plato. However, all other information contained in this extract is mythology. In particular, portraying Aristotle (Fig. 3) as hating observation is absolutely absurd.

A careful search in the literature reveals that this absurd idea about Aristotle, including the joke about women's teeth, is not Price's (1996) but Bertrand Russell's (1952):

Observation versus Authority: To modern educated people, it seems obvious that matters of fact are to be ascertained by observation, not by consulting ancient authorities. But this is an entirely modern conception, which hardly existed before the seventeenth century. Aristotle maintained that women have fewer teeth than men; although he was twice married, it never occurred to him to verify this statement by examining his wives' mouths. 

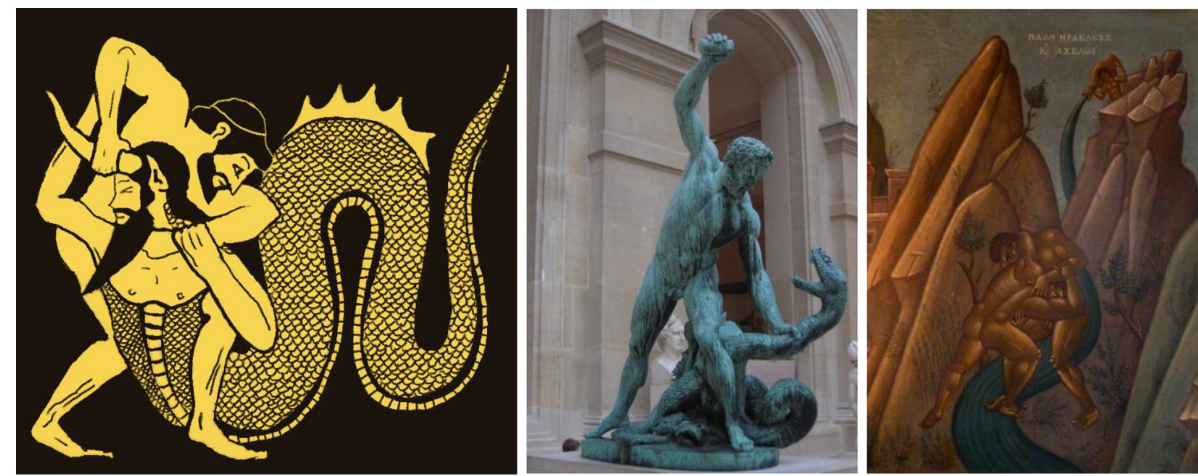

Figure 1. Different depictions of the mythological battle of Hercules against Achelous; (left) on an Attic red-figure vase, 6th century BC, kept in the British Museum (reproduced from Koutsoyiannis et al., 2007); (middle) in a modern sculpture, Hercule combattant Achéloüs métamorphosé en serpent by François Joseph Bosio in 1824 exhibited at the Louvre (source: https://commons.wikimedia.org/wiki/File: Hercule_Bosio_Louvre_LL325-1.jpg; last access: 30 March 2021); (right) on a wall painting in the Athens City Hall by Fotis Kontoglou in 1937-1939 with Byzantine aesthetics (reproduced from Koutsoyiannis et al., 2012).

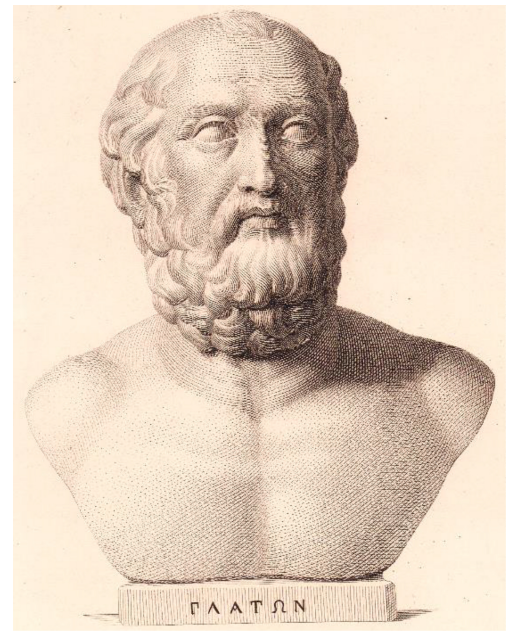

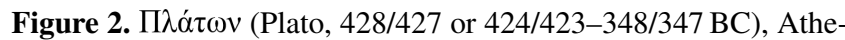
nian philosopher of the Classical period, founder of the Platonic School and the Academy, the first higher education institution in the Western World (image source: Visconti, 1817; see section on data availability for details).

Now, what Aristotle actually wrote was this:

Males have more teeth than females in the case of men, sheep, goats, and swine; in the case of other animals observations have not yet been made [...] The last teeth to come in man are molars called "wisdom-teeth", which come at the age of about twenty years, in the case of both men and women. Cases have been known in women upwards of eighty years old where at the very close of life the wisdom-teeth have come up. (Aristotle, History of Animals, 2.3.2-2.4.1; English translation by D'Arcy Wentworth Thompson; original: [OT2])

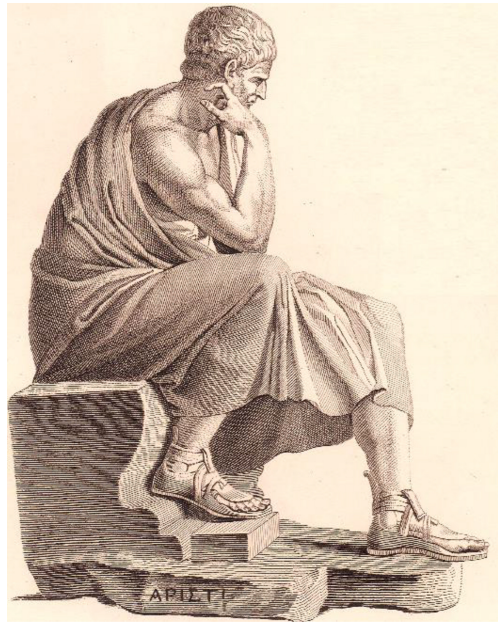

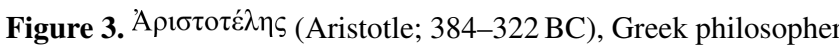
of the Classical period, founder of the Lyceum and the Peripatetic School of philosophy (image source: Visconti, 1817).

Which authority is right, Aristotle or Russell? Perhaps both - but they have different perceptions of nature. Russell seems to have a purely deterministic view, in which a rule, norm or formula (in this case the formula of 32 teeth per person) holds universally ${ }^{2}$. Aristotle, who is not a determinist (cf. his theory on potentiality and actuality; see Sect. 3), trusts empirical observation more - as evident in the extract.

\footnotetext{
${ }^{2}$ Russell does not provide information on how he knew whether or not Aristotle examined his two wives' teeth, nor whether or not he himself examined his four wives' teeth. By the way, we did not find it polite to examine our own wives' teeth, but this would be irrelevant. We know, of course, that each of the two of us has fewer than 32 teeth, while in the past one of us had 33, but again this does not enable any type of induction - for the latter we would need a large sample of observations.
} 
But what do we mean by observation? Does information from school teachers, professors, books, TV, the Internet, social media, model outputs, etc., count as observation? In our view not - and real observation can hardly confirm the universal validity of a formula referring to the real world. Some modern studies that could support the idea that what Aristotle wrote in the above excerpt is a result of observation are contained in the Supplement (Sect. S1).

After this necessary parenthesis on odontology, which has some epistemological interest, we return to hydrology, presenting another useful extract from Price (1996):

The first person to make a forthright and unequivocal statement that rivers and springs originate entirely from rainfall appears to have been a Frenchman called Bernard Palissy, who put forward this proposition in 1580 . Despite this, in the early 17 th century many workers were still in essence following the Greeks in believing that sea water was drawn into vast caverns in the interior of the Earth, and raised up to the level of the mountains by fanciful processes usually involving evaporation and condensation. The water was then released through crevices in the rocks to flow into the rivers and so back to the sea.

A similar extract from Todd and Mays (2005) is this:

As late as the seventeenth century it was generally assumed that water emerging from springs could not be derived from rainfall, for it was believed that the quantity was inadequate and the earth too impervious to permit penetration of rainwater far below the surface. Thus, early Greek philosophers such as Homer, Thales, and Plato hypothesized that springs were formed by seawater conducted through subterranean channels below the mountains, then purified and raised to the surface. Aristotle suggested that air enters cold dark caverns under the mountains where it condenses into water and contributes to springs.

Finally, a recent text on the history of hydrology by Rosbjerg and Rodda (2019) contains the following:

It was, however, not before the beginning of the 1500 s that a scientific approach to hydrology started to take off, albeit with a very slow starting speed. Leonardo da Vinci undertook physical experiments, e.g. measuring stream velocity, to support his advanced thoughts about hydrology [...]. In 1575, Bernard Palissy, based on observations in nature, claimed that springs originated from rain, and 100 years later, in 1674, Pierre Perrault measured the rainfall, runoff and drainage area of the Seine River and concluded that rainfall was enough to support springs and rivers. The pathways, however, were not correctly described. In 1686, Edme Mariotte supported the findings of Perrault by contributing infiltration experiments, relating them to precipitation regimes and developing better streamflow measurements. Around 1700, Edmond Halley published the results of evaporation measurements, thereby contributing significantly to closing the hydrological cycle. Nevertheless, it was not before 1802 that John Dalton became the first to give a complete and correct description of the cycle based on reliable observations. [...]

At the general assembly of the IUGG in Rome in 1922, a delegate proposed a motion to form an additional section within the union to deal with the scientific problems in hydrology, such as "rivergauging, lake phenomena including seiches, runoff and evaporation, transport of material in suspension and in solution, glacier movement, etc." A committee was set up to give its opinion on the desirability of such a new activity. The committee gave favourable advice and proposed that the new organism should be named Section of Scientific Hydrology. The adjective "scientific" was added to distinguish the section's participants from the "charlatans and simpletons", who with the help of all sorts of rods tried to find water, calling themselves hydrologists, and also to make clear that the branch would not deal with the commercial exploitation of mineral waters.

In the following sections we will see that all above extracts contain useful information but also serious misinformation about the history of hydrology. Our method, already illustrated above, is to retrieve the ancient documents in their original version and quote relevant extracts rather than resort to what modern scholars have said about them. All original extracts (mostly in Greek) are given in the Supplement, Sect. S4. We will see that not only was the notion of the hydrological cycle known to Ancient Greek scholars, but that hydrology also appeared in the cradle of science. The first geophysical problem posed was hydrological: the explanation of the flooding of the Nile. The problem plagued scientists for almost 3 centuries before it was resolved by Aristotle. We will also trace the links of the developments in the early modern period (after the Renaissance) with the ancient thinkers, including Aristotle and Hippocrates; it is the strong link with the latter and the health aspects of water that dictated the adjective "scientific" in hydrology in the beginning of the 20th century. In other words, the need to distinguish it from the "charlatans and simpletons" (Rosbjerg and Rodda, 2019) does not correspond to reality - unless one characterizes medical doctors as such, which hopefully is not the case. 
However, before we proceed to the ancient and early modern developments in hydrology, it is useful to find the origin of the misunderstanding of what Ancient Greek science actually was. After some searching in classical Greek texts, we suspect that the culprit is Plato, and the misunderstanding stems from the following passage from his dialogue Phaedo:

[Socrates:] One of the chasms of the earth is greater than the rest, and is bored right through the whole earth; this is the one which Homer means when he says "Far off, the lowest abyss beneath the earth" and which elsewhere he and many other poets have called Tartarus. For all the rivers flow together into this chasm and flow out of it again, and they have each the nature of the earth through which they flow. $[\ldots]$ And when the water retires to the region which we call the lower, it flows into the rivers there and fills them up, as if it were pumped into them; and when it leaves that region and comes back to this side, it fills the rivers here. (Plato, Phaedo, 14.112; English translation by Harold North Fowler; original: [OT3])

While this story in Phaedo was adopted by many thinkers and scientists from Seneca (c. 4 BC-AD 65) to Descartes (1596-1650), it is a just a poetic metaphor, as indicated by the reference to Homer. It has a symbolic meaning as the philosophical subject of Phaedo is the immortality of the soul. It is not representative of Greek philosophers' views on nature, not even Plato's. In other dialogues, Plato offers more consistent theories, e.g. in Critias:

[Critias:] Moreover, it was enriched by the yearly rains from Zeus, which were not lost to it, as now, by flowing from the bare land into the sea; but the soil it had was deep, and therein it received the water, storing it up in the retentive loamy soil and by drawing off into the hollows from the heights the water that was there absorbed, it provided all the various districts with abundant supplies of springwaters and rivers. (Plato, Critias, 111d; translation adapted from Robert Gregg Bury; original: [OT4])

Interestingly, in this excerpt Zeus is responsible for the rainfall process, the most complex and most difficult to understand. All other transformations of water throughout the hydrological cycle are natural. As we will see in the next sections, others have completely expelled Zeus and other gods from the entire hydrological cycle.

Critics of Plato with respect to his scientific views should be aware that he was the author of the first work in history about epistemology, i.e. his dialogue Theaetetus, and the first

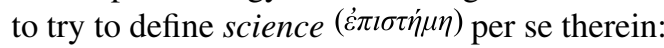

[Theaetetus:] Science is true judgment, affirmed by reason, but that unreasoned is outside of the sphere

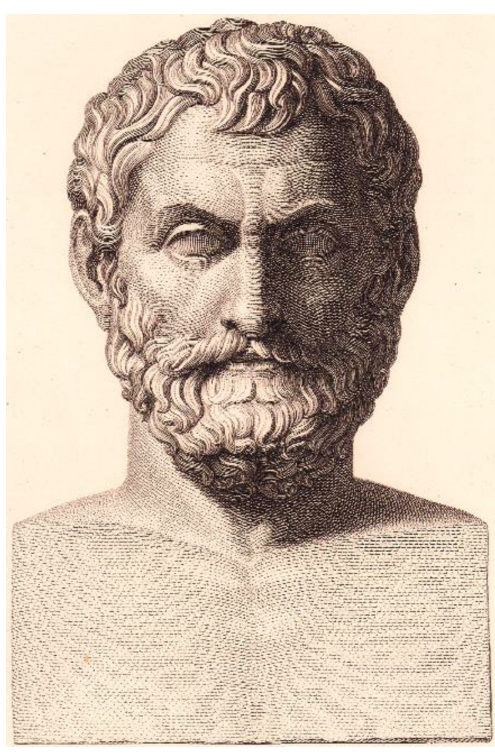

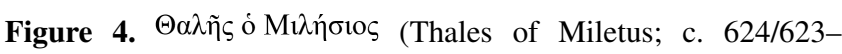
c. 548/545 BC), one of the Seven Sages of Greece, the first philosopher in the Greek tradition also recognized as the father of science (image source: Visconti, 1817).

of science. (Plato, Theaetetus, 201d; translation by the authors; original: [OT5])

Moreover, in his dialogue Republic, Plato gives the following definition of philosophers, who in that period were not actually distinguished from scientists:

[Glaucon:] Who then are the true philosophers? [Socrates:] Those, I said, who are lovers of the vision of truth. (Plato, Republic, V, 475e; English translation by Benjamin Jowett; original: [OT6])

\section{Hydrology at the birth of science}

Natural philosophy - or, in modern vocabulary, science - begins with Thales of Miletus (Fig. 4), one of the Seven Sages of Greece and the father of the Ionian philosophical school. (Ionia was located on the western coast of Asia Minor by the Aegean Sea, which was inhabited by Greeks from ancient times till AD 1922). As a philosopher, he is famous for the foremost importance he gave to water as a natural element as well as for several apothegms. ${ }^{3}$ As a scientist he is known for his contribution in several areas, i.e.

\footnotetext{
${ }^{3}$ Different scholars may attribute each of them to more than one of the Seven Sages. However, it would be relevant to mention two of them that could be useful to hydrolo-

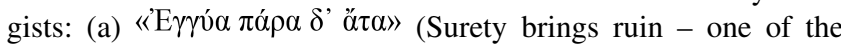
three maxims inscribed on the temple of Apollo in Delphi) (b)

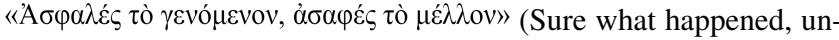
clear the future).
} 
- Mathematics. He introduced deduction through theorems; he proved several theorems in geometry, including those bearing his name: the Thales' angle theorem and the interception theorem.

- Astronomy. He predicted the solar eclipse in 28 May $585 \mathrm{BC}$.

- Physics. He studied static electricity by experimenting on amber (in Greek $\eta \dot{\lambda \varepsilon \kappa \tau \rho o v ~-~ e l e c t r o n) ~ a s ~ w e l l ~ a s ~ m a g-~}$ netism.

- Surveying engineering. He measured the heights of pyramids and the distance of ships from the shore.

- Hydraulic engineering. He made a diversion of the Halys River for military purposes.

His contribution to hydrology is less known, but it is important as he formulated for the first time in history a hydrological behaviour as a scientific problem, thus highlighting the importance of hydrology in the cradle of science. The problem is the so-called paradox of the Nile and, as we will see in Sect. 4, the solution he gave is clearly wrong. Yet the important development is that he formulated the problem in scientific terms, expelling the divine element from natural processes.

Anaximander (c. 610-c. 546 BC), who succeeded Thales

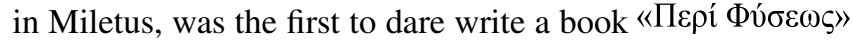
("On Nature"; lost) rejecting mythological and religious views. He understood the relationship of rainfall and evaporation:

Rain [is created] from the vapours which rise from earth by the sun. (Hippolytus, Refutation of All Heresies, I, 5; translation by the authors; original: [OT7])

Anaximenes (c. 586-c. 526 BC), another philosopher from Miletus, pupil of Anaximander, proclaimed air as the arche (origin) of the universe; naturally, thus, he devised logical explanations for the formation of wind, clouds, rain and hail:

the winds arise when the air becomes partially condensed and is lifted up; and when it comes together and more condensed, clouds are generated, and thus a change is made into water. And hail is produced when the water precipitating from the clouds freezes; and snow is generated when these clouds, being more moist, acquire congelation; and lightning is caused when the clouds are parted by force of the winds; $[\ldots]$. And a rainbow is produced from solar rays falling on condensed air. (Hippolytus, Refutation of All Heresies, I, 6; translation by the authors; original: [OT8])

The entire hydrological cycle was described by Xenophanes (c. 570-478 BC), another Ionian philosopher, who

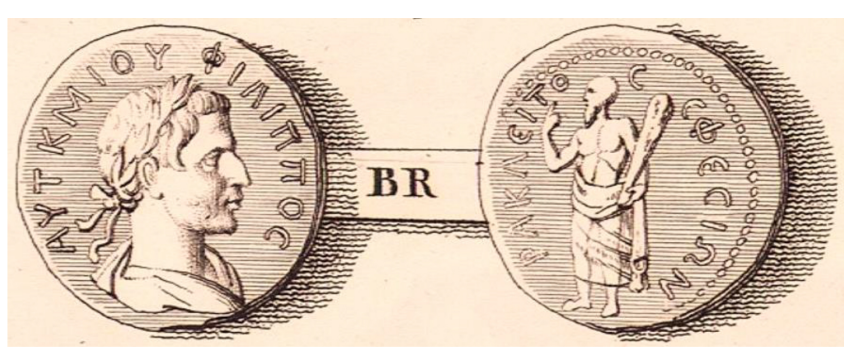

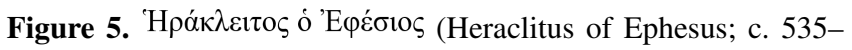
c. $475 \mathrm{BC})$, Ionian philosopher, father of dialectics, depicted in the back facet of a coin whose front facet shows Philip (image source: Visconti, 1817).

supported his theory by the discovery of fossilized marine organisms at three island locations. Hippolitus (c. AD 170235; Christian theologian) attributes to him a theory of alternating periods of flood and drought. Xenophanes expressed his philosophy in poetic form (hexameters, elegies, iambics), as in the following fragment:

The sea is the source of water and the source of wind; for neither in the clouds $<$ would there be nor any blasts of wind blowing forth $>$ from within, without the mighty sea, nor river flows nor rain water from the sky. The mighty sea is creator of clouds and of winds and of rivers. (Fragment B 30, recovered from Geneva Scholia on Homer; translation by the authors; original: [OT9])

Hydrology is the science of change and randomness; Heraclitus (Fig. 5) described the nature of each in just a few words, using the metaphor of flow in the first case and of dice in the second case:

- $\Pi \dot{\alpha} v \tau \alpha \dot{\rho} \varepsilon \tilde{l}$

(Everything flows; Heraclitus; quoted in Plato's Cratylus, 339-340)

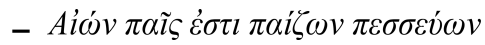

(Time is a child playing, throwing dice; Heraclitus; fragment 52)

Interestingly, the former aphorism has become the emblem of the current hydrological decade (Montanari et al., 2013). The latter symbol, the dice, was used in other famous aphorisms such as by Julius Caesar and by Einstein. Einstein expressed (in a less poetic manner) exactly the opposite view; however, the recent developments in physics seem to vindicate Heraclitus.

Anaxagoras of Clazomenae (Fig. 6) was another Ionian philosopher who proved to be very influential in history. As he moved to Athens and taught there for about 30 years, he transplanted the ideas of Ionian philosophers to Athenians, having prominent students such as Pericles, Euripides, 


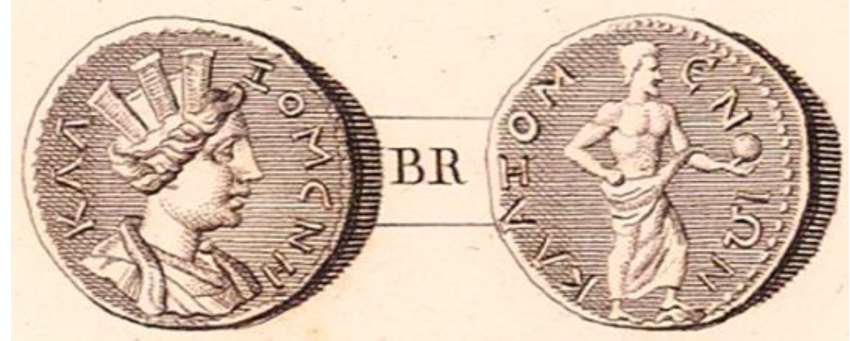

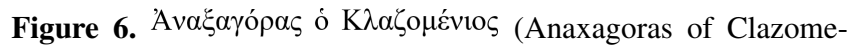
nae; c. 500-c. 428 BC), the philosopher who transplanted the Ionian philosophy to Athens, depicted in the back facet of a coin whose front facet shows a ribbed head of a woman representing the personified city of Clazomenae (image source: Visconti, 1817).

Sophocles, and Herodotus. He proposed a theory of "everything in everything" and was the first to give a correct explanation of eclipses. While his scientific theories were mostly related to astronomy, including the claims that the sun is a mass of red-hot metal and the moon is earthy, they also include hydrology:

The rivers receive their contents from the rains and from the waters in the earth; for the earth is hollow and has water in its hollow portions. (Hippolytus, Refutation of All Heresies, I, 8; translation by M. David Litwa; original: [OT10])

Subsequently, Athens became the philosophical, scientific and political centre of the entire world for several centuries. This may seem a historical paradox because it is a dry and infertile place. The paradox was explained by the Athenian Thucydides (Fig. 7), father of scientific history, who observed that infertility also has a good side and that scarcity may be preferable to abundance:

The richest soils were always most subject to this change of masters; such as the district now called Thessaly, Boeotia, most of the Peloponnese, Arcadia excepted, and the most fertile parts of the rest of Hellas. The goodness of the land favoured the aggrandizement of particular individuals, and thus created faction which proved a fertile source of ruin. It also invited invasion. Accordingly Attica, from the poverty of its soil enjoying from a very remote period freedom from faction, never changed its inhabitants. And here is no inconsiderable exemplification of my assertion that the migrations were the cause of there being no correspondent growth in other parts. The most powerful victims of war or faction from the rest of Hellas took refuge with the Athenians as a safe retreat; and at an early period, becoming naturalized, swelled the already large population of the city to such a height that Attica became at last too small to hold them, and they

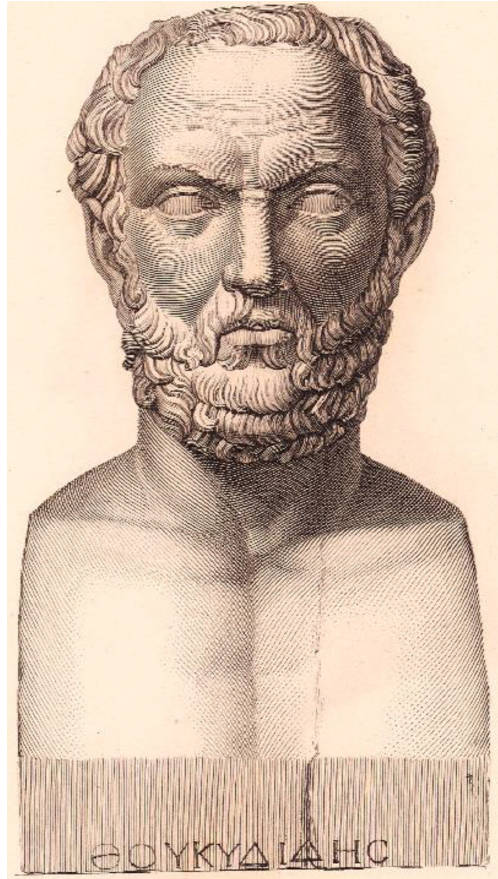

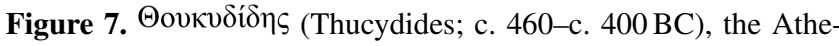
nian historian dubbed the father of scientific history (image source: Visconti, 1817).

had to send out colonies to Ionia. (Thucydides, The Peloponnesian War, 1.2.3-6; English translation by Richard Crawley; original: [OT11])

Among the philosophers who lived and taught in Athens, Aristotle has been the most influential in subsequent developments of philosophy and science, including hydrology; therefore, we devote to him the entire Sect. 3. Among those who lived in other places of Greece in the Classical period, the historian Herodotus from Halicarnassus is mentioned in Sect. 4, while here we should also mention Hippocrates (Fig. 8), who lived on the island of Kos. He is often referred to as the father of medicine, but, as we will see, his contribution to ancient and modern hydrology through his treatise On Airs, Waters, Places is not negligible. From this treatise we quote the following passage, in which he describes the hydrological cycle:

Rain waters, then, are the lightest, the sweetest, the thinnest, and the clearest; for originally the sun raises and attracts the thinnest and lightest part of the water, as is obvious from the nature of salts; for the saltish part is left behind owing to its thickness and weight, and forms salts; but the sun attracts the thinnest part, owing to its lightness, and he abstracts this not only from the lakes, but also from the sea, and from all things which contain humidity, and there is humidity in everything; and from man himself the sun draws off the thinnest 


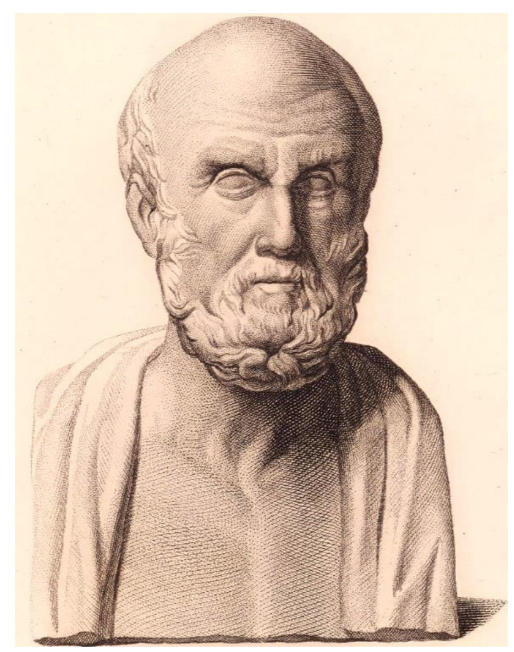

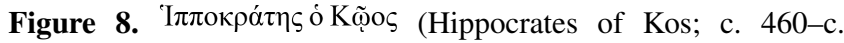
$370 \mathrm{BC})$, the philosopher and physician of Classical Greece who is considered one of the most outstanding figures in the history of medicine (image source: Visconti, 1817).

and lightest part of the juices. [...] And in addition to this, when attracted and raised up, being carried about and mixed with the air, whatever part of it is turbid and darkish is separated and removed from the other, and becomes cloud and mist, but the most attenuated and lightest part is left, and becomes sweet [i.e. fresh], being heated and concocted by the sun, for all other things when concocted become sweet. While dissipated then and not in a state of consistence it is carried aloft. But when collected and condensed by contrary winds, it falls down wherever it happens to be most condensed. (Hippocrates, De Aere Aquis et Locis, 8; English translation adapted from William Henry Samuel Jones; original: [OT12])

In another passage, he expresses (in addition to the link of water and wine, which Ancient Greeks used to mix) the relationship of spring water temperature and depth of its origin:

The best [waters] are those that flow from high places and earthy hills. By themselves they are fresh and clear, and the wine they can stand is but little. In winter they are warm, in summer cold. They would naturally be so, coming from very deep springs. (bid., 7; original: [OT13])

Apparently, the reference to "warm" and "cold" should be read relative to the environmental temperature as Hippocrates did not have an instrument to measure temperature in objective terms. Today we measure temperature to infer the depth.

Compared to modern knowledge, that contained in the above extracts of the ancient philosophers is incomplete and sometimes erroneous. This is normal as scientific knowledge is a result of an endless and torturous process. It is not revelation knowledge like in religion.

\section{Aristotle}

Aristotle was a student of Plato, but his theories were influenced by Ionian philosophers. Instead of continuing in Plato's Academy, he founded his own school, known as the

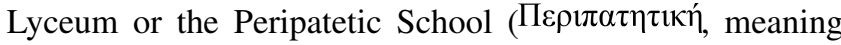
"by walking about"). His theories expand to all aspects of knowledge and are relevant not only in his period, but also throughout the entire history of science, including the recent period. Science and the scientific method owe him basic notions on research and laws on inference, sometimes referred to as Aristotelian logic, expounded in his six books that are collectively known as the Organon, as well in his book Metaphysics. These include the laws of identity (Prior Analytics, 2.22.68a), the excluded middle and noncontradiction (Metaphysics, 4.1011b, 4.1006b, 4.1008a) and the distinction of

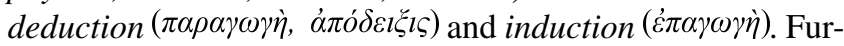
thermore, the principle of parsimony (also known as Ockham's razor) is expressed in at least three of Aristotle's books (Posterior Analytics, I.25; On the Heavens, III.4; Nicomachean Ethics, 1094b).

Another concept introduced by Aristotle that has acquired great importance in modern science, particularly in physics

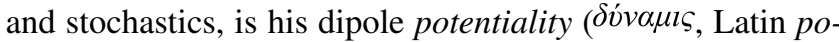
tentia) vs. actuality (Evé $\rho \gamma \varepsilon l \alpha$, Latin actualitas), formulated in his books Physics, Metaphysics, Nicomachean Ethics and De Anima. The first to utilize the dipole in modern science, namely in quantum physics, was Heisenberg (1962):

The most important of these [features of the interpretation by Bohr, Kramers and Slater] was the introduction of the probability as a new kind of "objective" physical reality, the "potentia" of the ancients such as Aristotle; it is, to a certain extent, a transformation of the old "potentia" concept from a qualitative to a quantitative idea.

This idea of Heisenberg was quoted by Popper (1982), who fully incorporated it into his philosophical system, further extending it to claim, for example, that "Both classical physics and quantum physics are indeterministic". More recently this Aristotelian dipole has been proposed by several scientists and philosophers, independently of Popper, as a simpler, more comprehensible and more effective interpretation of quantum physics (Jaeger, 2017, 2018; Kastner et al., 2018; Driessen, 2019; Sanders, 2018). In particular, Kastner et al. (2018), building on Heisenberg's (1962) idea, propose an ontological dualism of actualities (res extensa) and potentia (res potentia), with the latter not bounded by space-time constraints and being transformed to the former by an acausal process. 
Now coming to Aristotle's proposals that focus on hydrological processes, we should first mention his treatise Meteorologica, which offers a great contribution to the explanation of hydrometeorogical phenomena. As we know, the entire hydrological cycle is based on the phase change of water, which Aristotle understood in this way:

We maintain that fire, air, water and earth are transformable one into another, and that each one potentially exists in the others, as all have a single common underlying substratum, in which are ultimately resolved. (Meteorologica, I.1, 339a, b; English translation adapted from Lee, 1952; original: [OT14])

The sun causes the moisture to rise; this is similar to what happens when water is heated by fire. (ibid., II.2, 355a 15; original: [OT15])

The vapour that is cooled, for lack of heat in the area where it lies, condenses and turns from air into water; and after the water has formed in this way it falls down again to the earth; the exhalation of water is vapour; air condensing into water is cloud. (ibid., I.9, 346b 30; original: [OT16])

In addition, he recognized the principle of mass conservation within the hydrological cycle:

Thus, [the sea] will never dry up; for [the water] that has gone up beforehand will return to it. (ibid., II.3, 356b 26; original: [OT17])

Even if the same amount does not come back every year or in a given place, yet in a certain period all quantity that has been abstracted is returned. (ibid., II.2, 355a 26; original: [OT18])

Furthermore, Aristotle penetrated into the concept of change. He was fully aware that the Earth changes through the ages and that rivers are formed and disappear in the course of time:

But if rivers are formed and disappear and the same places were not always covered by water, the sea must change correspondingly. And if the sea is receding in one place and advancing in another it is clear that the same parts of the whole earth are not always either sea or land, but that all changes in course of time. (ibid., I.14, 353a 16; original: [OT19])

In the introduction we stressed the importance given by Aristotle to observation, and the above quotation illustrates his ability to generalize an observation (possibly of fossilized marine organisms in land) and proceed in formulation of a scientific hypothesis and inference by reasoning. In addition to observation, he conducted experimentation. In the following passage he explains that he found by experiment that the salt contained in water is not evaporated:
Salt water when it turns into vapour becomes drinkable [freshwater] and the vapour does not form salt water when it condenses again; this we know by experiment. (ibid., II.3, 358b; original: [OT20])

Here it is useful to notice Aristotle's formal scholarly writing style; thus, in the last phrase we notice the first-person plural, the so-called editorial "we" (typically meaning "I, the writer, and you, the reader"). ${ }^{4}$ Yet we note that the editorial "we" is much earlier as it was used even by Homer in the tenth verse of the Odyssey: "Of these things, goddess, daughter of Zeus, tell to us" 5 . Even though nowadays several editors advise against its use and prefer a third-person passive voice (e.g. "it is known by experiment"), we may recognize several advantages in Aristotle's vivid expression in the active voice (e.g. in [OT14] and [OT20], also noting that he did not fully exclude the passive voice, e.g. in [OT2]).

The knowledge resulting from Aristotle's experiment has certainly found technological application in desalination (removal of salt from sea water), useful in a country with scarcity of freshwater and many shores and islands. Thus, we learn from a commentary on Aristotle's Meteorologica II, written by Olympiodorus the Peripatetic (a 5th-century philosopher), that

Sailors, when they labour under a scarcity of fresh water at sea, boil the sea-water, and suspend large sponges from the mouth of a brazen vessel, to imbibe what is evaporated, and in drawing this off from the sponges, they find it to be sweet [fresh] water. $^{6}$

\section{The Nile paradox and its solution by Aristotle}

As already mentioned in the introduction, the flooding of the Nile was the first geophysical problem posed in scientific terms. The problem plagued scientists for almost 3 centuries before it was resolved by Aristotle, but it took much more before this correct explanation was generally accepted by the scientific community. What was regarded as a paradox is the different hydrological regime compared to other Mediterranean rivers: Nile floods occur in summer. Figure 9 illustrates the reasons why it was regarded as a paradox using modern data of the Nile flows on a monthly scale, along with monthly precipitation data at stations in the wider area.

\footnotetext{
${ }^{4}$ This is clear in the original [OT20], where in the phrase

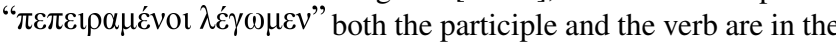
plural; the phrase is usually translated into English in the singular, "this I know by experiment", but this does not correspond to the original.

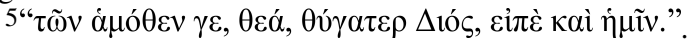

${ }^{6}$ Quoted from Morewood (1838); see also quotation by Alexander of Aphrodisias, peripatetic philosopher (fl. AD 200), in Forbes (1970).
} 

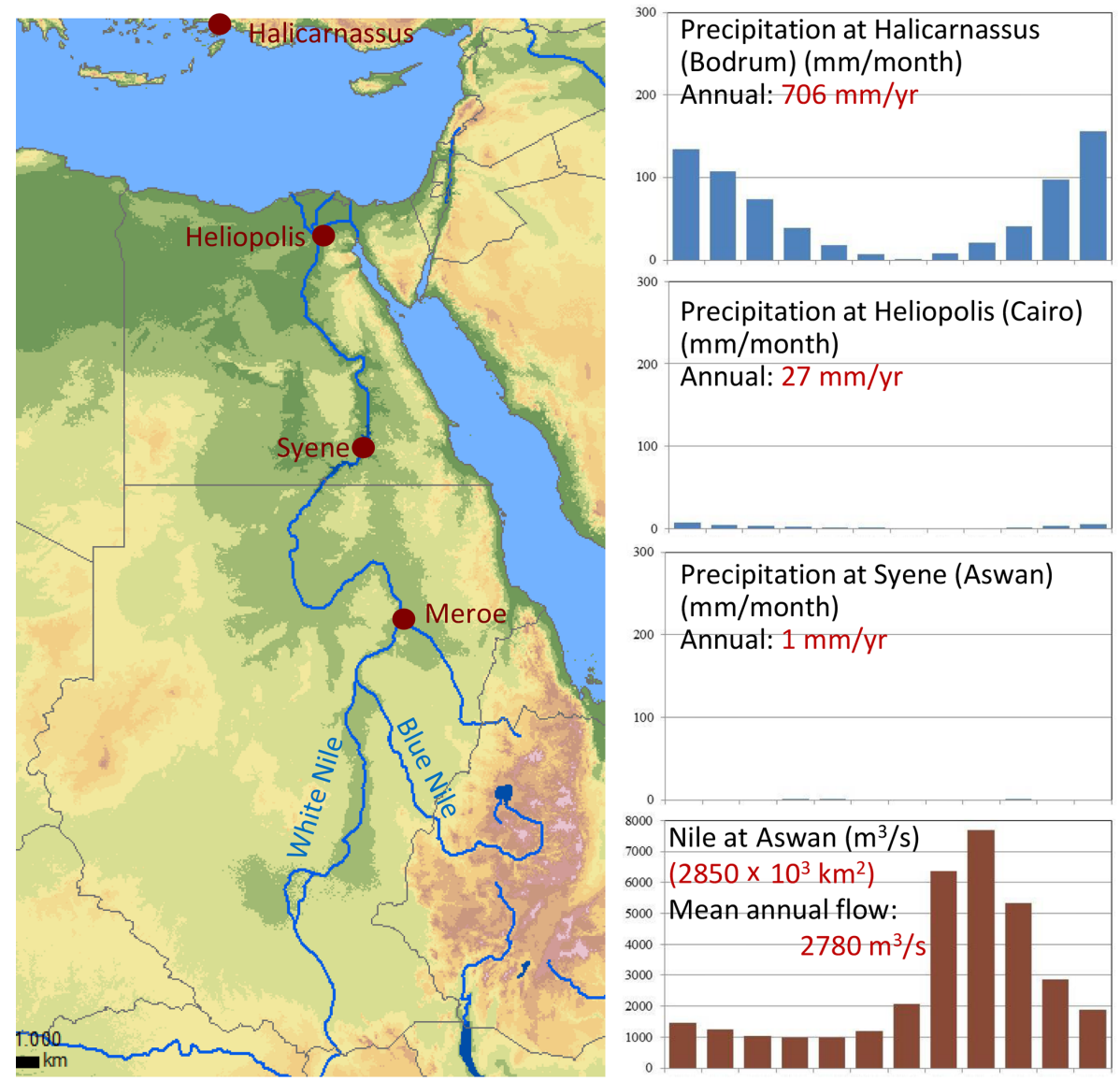

Figure 9. Map of the Nile area along with graphs of mean monthly precipitation (from modern measurements; months January to December) at characteristic ancient sites and mean monthly flow at Aswan (Syene).

The problem was originally stated by the historian Herodotus (Fig. 10) in the following manner:

Concerning the nature of the river, I was not able to gain any information either from the priests or from others. I was particularly anxious to learn from them why the Nile, at the commencement of the summer solstice, begins to rise, and continues to increase for a hundred days - and why, as soon as that number is past, it forthwith retires and contracts its stream, continuing low during the whole of the winter until the summer solstice comes round again. On none of these points could I obtain any explanation from the inhabitants, though I made every inquiry, wishing to know what was commonly reported - they could neither tell me what special virtue the Nile has which makes it so opposite in its nature to all other streams, nor why, unlike every other river, it gives forth no breezes from its surface. (Herodotus, The Histories, 2, 19, English translation by George Rawlinson; original: [OT21])
Herodotus' spirit to seek physical explanations for natural phenomena, which reflects the more general trend developed in Greece after Thales, is contrasted here with the Ancient Egyptian people's attitude (including their priests), who seem to have been uninterested in physics. Subsequently, Herodotus describes three explanations given by the Greeks, without mentioning their names but only their ambition to achieve a reputation for wisdom:

Some of the prominent Greeks, however, wishing to get a reputation for wisdom, have offered explanations of the phenomena of the river, for which they have accounted in three different ways. Two of these I do not think it worth while to speak of, further than simply to mention what they are. (ibid. 2, 20; original: [OT22])

The first explanation is this:

One says that the Etesian [i.e. monsoon] winds cause the rise of the river by preventing the Nilewater from running off into the sea. But in the first place it has often happened, when the Etesian 


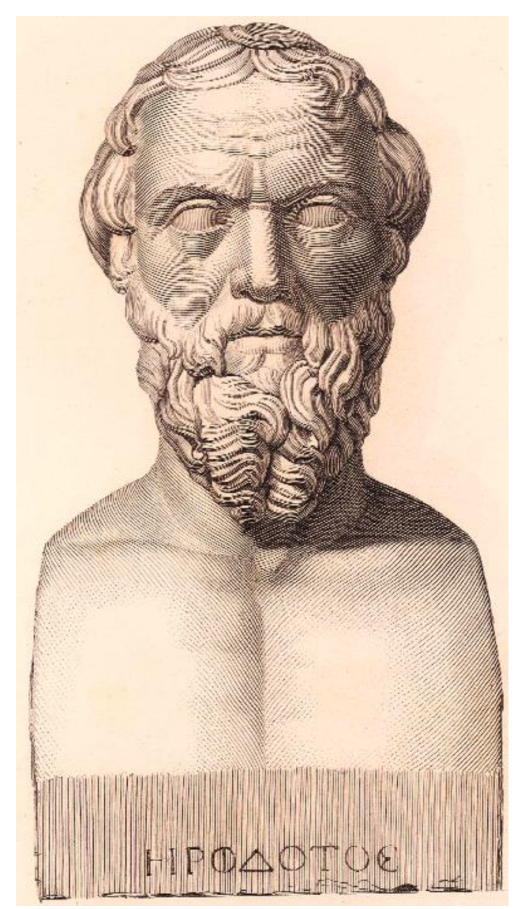

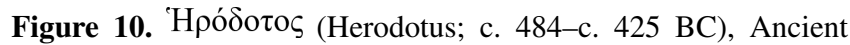

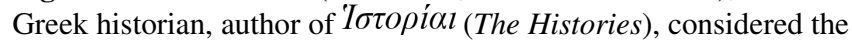
first to have treated historical subjects using a method of systematic investigation (by collecting materials and then critically arranging them into a historiographic narrative) (image source: Visconti, 1817).

winds did not blow, that the Nile has risen according to its usual wont; and further, if the Etesian winds produced the effect, the other rivers which flow in a direction opposite to those winds ought to present the same phenomena as the Nile, and the more so as they are all smaller streams, and have a weaker current. But these rivers, of which there are many both in Syria and Libya, are entirely unlike the Nile in this respect. (ibid. 2, 20; original: [OT23])

He continues:

The second opinion is even more unscientific than the one just mentioned, and also, if I may so say, more marvellous. It is that the Nile acts so strangely, because it flows from the ocean, and that the ocean flows all round the earth. [...] As for the writer who attributes the phenomenon to the ocean, his account is involved in such obscurity that it is impossible to disprove it by argument. For my part I know of no river called Ocean, and I think that Homer, or one of the earlier poets, invented the name, and introduced it into his poetry. (ibid. 2, 21\&23; original: [OT24])

Finally:
The third explanation, which is very much more plausible than either of the others, is positively the furthest from the truth; for there is really nothing in what it says, any more than in the other theories. It is, that the inundation of the Nile is caused by the melting of snows. Now, as the Nile flows out of Libya, through Ethiopia, into Egypt, how is it possible that it can be formed of melted snow, running, as it does, from the hottest regions of the world into cooler countries? Many are the proofs whereby any one capable of reasoning on the subject may be convinced that it is most unlikely this should be the case. The first and strongest argument is furnished by the winds, which always blow hot from these regions. The second is that rain and frost are unknown there. Now whenever snow falls, it must of necessity rain within five days, so that, if there were snow, there must be rain also in those parts. Thirdly, it is certain that the natives of the country are black with the heat, that the kites and the swallows remain there the whole year, and that the cranes, when they fly from the rigors of a Scythian winter, flock thither to pass the cold season. If then, in the country whence the Nile has its source, or in that through which it flows, there fell ever so little snow, it is absolutely impossible that any of these circumstances could take place. (ibid. 2, 22; original: [OT25])

Information about who supported each of the three explanations was later given by other authors, e.g. Aetius, the 1stor 2nd-century AD doxographer and Eclectic philosopher. Interestingly, the first explanation is attributed to Thales, which verifies our claim about the strong link of hydrology with science (or natural philosophy), at the dawn of the latter:

Thales thinks that the Etesian winds [monsoons], blowing straight on to Egypt, raise up the mass of the Nile's water through cutting off the outflow by the swelling of the sea coming against it. (Aetius IV, 1, 1; original: [OT26])

The second view was supported by Euthymenes of Mas-

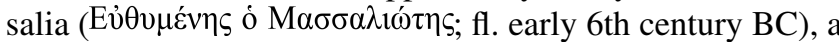
Greek explorer from Massilia (Marseille), who explored the coast of western Africa. The third seems to have been supported by Anaxagoras and in another version by Democritus (460-370 BC).

Herodotus does not accept any of the three explanations and proceeds to give his own:

Perhaps, after censuring all the opinions that have been put forward on this obscure subject, one ought to propose some theory of one's own. I will therefore proceed to explain what I think to be the reason of the Nile's swelling in the summer time. During the winter, the sun is driven out of 
his usual course by the storms, and removes to the upper parts of Libya. This is the whole secret in the fewest possible words; for it stands to reason that the country to which the Sun-god approaches the nearest, and which he passes most directly over, will be scantest of water, and that there the streams which feed the rivers will shrink the most. (Herodotus, The Histories, 2, 24; English translation by George Rawlinson; original: [OT27])

Apparently, all explanations are wrong. Yet two of them, the first and the third, are scientific, while the second is mythical and Herodotus' one contains mythical elements and a belief in a flat Earth.

In the above quotations and with respect to the writing style, we may observe that, in contrast to Aristotle's "we", Herodotus (who anticipated Aristotle by a century) uses the looser, less scholarly, singular "I" (noting that in all the above quotations the original syntax is in the first person, despite some appearances in the third person in the English translation). Herodotus is a fascinating writer, but his writings are not devoid of mythical and imaginative elements. Yet the information he provides is precious, including for hydrological and climatic conditions of the many places he visited and the achievements in hydraulic constructions of several civilizations (Katsifarakis and Avgoloupis, 2013, 2019; Koutsoyiannis, 2021).

Modern knowledge of the hydrological regime of the Nile's basin, illustrated in Fig. 11 by means of graphs of monthly flow and precipitation at several sites, clearly shows that the origin of floods are the high precipitation rates in the Blue Nile in Ethiopia, driven by monsoons and peaking in July and August.

Was any ancient philosopher able to find a correct explanation? In particular, what was the opinion of Aristotle, who lived a century after Herodotus? Here comes another puzzle, which seems to have been resolved very recently. The reason for such a delay is the fact that most of the Greek texts, which certainly contained relevant information, have been lost. Alexandria's library was accidentally burned by Romans at least twice (by Julius Caesar and Aurelian) and perhaps re-destroyed by Arabs (Caliph Omar). The Imperial Library of Constantinople was destroyed in 1204 by the knights of the Fourth Crusade, whilst in 1453, the Fall of Constantinople, conquered by Ottoman Turks, was accompanied by destruction of the city's libraries.

Among the manuscripts that were saved, one is Patriarch Photius' (c. 810/820-893) Myriobiblon or Biblioteheca, composed of 279 reviews of books which he had read. This, perhaps the first in history, collection of book reviews, written in Greek, was printed in 1611 with a Latin translation (Fig. 12). One of the books reviewed is a lost one entitled Life of Pythagoras by an anonymous author. The book contained important information about Aristotle's decisive contribution in solving the Nile paradox, which Photius summarizes as follows:

The Etesian winds [i.e. monsoons] blow during the peak of the summer for this reason: The sun, at the zenith passing from south to north, disintegrates the moisture from the arctics and once this moisture is disintegrated, it evaporates and gives rise to monsoons [...] When they reach the high mountains of Ethiopia and concentrate there, they produce rains. These rains in full summer cause the flood of the Nile and make it overflow, while it flows at the northern arid regions. This was analysed by Aristotle, who, by the superiority of his mind, understood it. He demanded to send Alexander of Macedonia to these regions, and to find, by sight, the cause of the flooding of the Nile. That is why they say there is not a problem anymore. It became apparent by sight that the flow is increased by these rains. And this solved the paradox that in the driest Ethiopian [i.e. African] places where there is no winter nor rain, it happens that in the summer strong rainfalls occur. (Photius, 1611, On Life of Pythagoras by Anonymous, translation by the authors; original: [OT28])

One should remember that Alexander (Fig. 13) was a student of Aristotle and exchanged letters with him (and his mother Olympias), addressing him as professor ( $\kappa \alpha \theta \eta \eta \eta \tau \eta े v)$ during his campaign to Asia and Africa. Therefore, the information contained in the latter extract is not implausible. In our view this is very important information as it describes the first scientific expedition in history in order to confirm a scientific hypothesis.

Confirmation of the truth of the story is provided

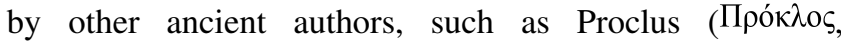
AD 412-485; Neoplatonist philosopher), John the Lydian

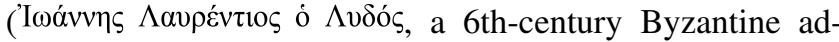
ministrator) and Cleomedes (K $\lambda \varepsilon \circ \mu \eta \dot{\delta} \delta \eta$, an astronomer who lived some time between the mid-1st century BC and AD 400):

Eratosthenes, however, says, it is no longer requisite to investigate the cause of the increase of the Nile, once some have reached at the springs of the Nile and saw the rains that occur there, so as to corroborate what is said by Aristotle. (Proclus, Commentary on Plato's Timaeus, 22 E - I 121, English translation by Thomas Taylor; original: [OT29])

For since Ethiopia is girdled by mountains higher than ours, as it receives the clouds that are driven by the Etesian [winds], the Nile swells. As Callisthenes the Peripatetic also says in the fourth book of his Hellenica that he campaigned with Alexander the Macedonian, and when he was in Ethiopia he found that the Nile is driven down by the endless 


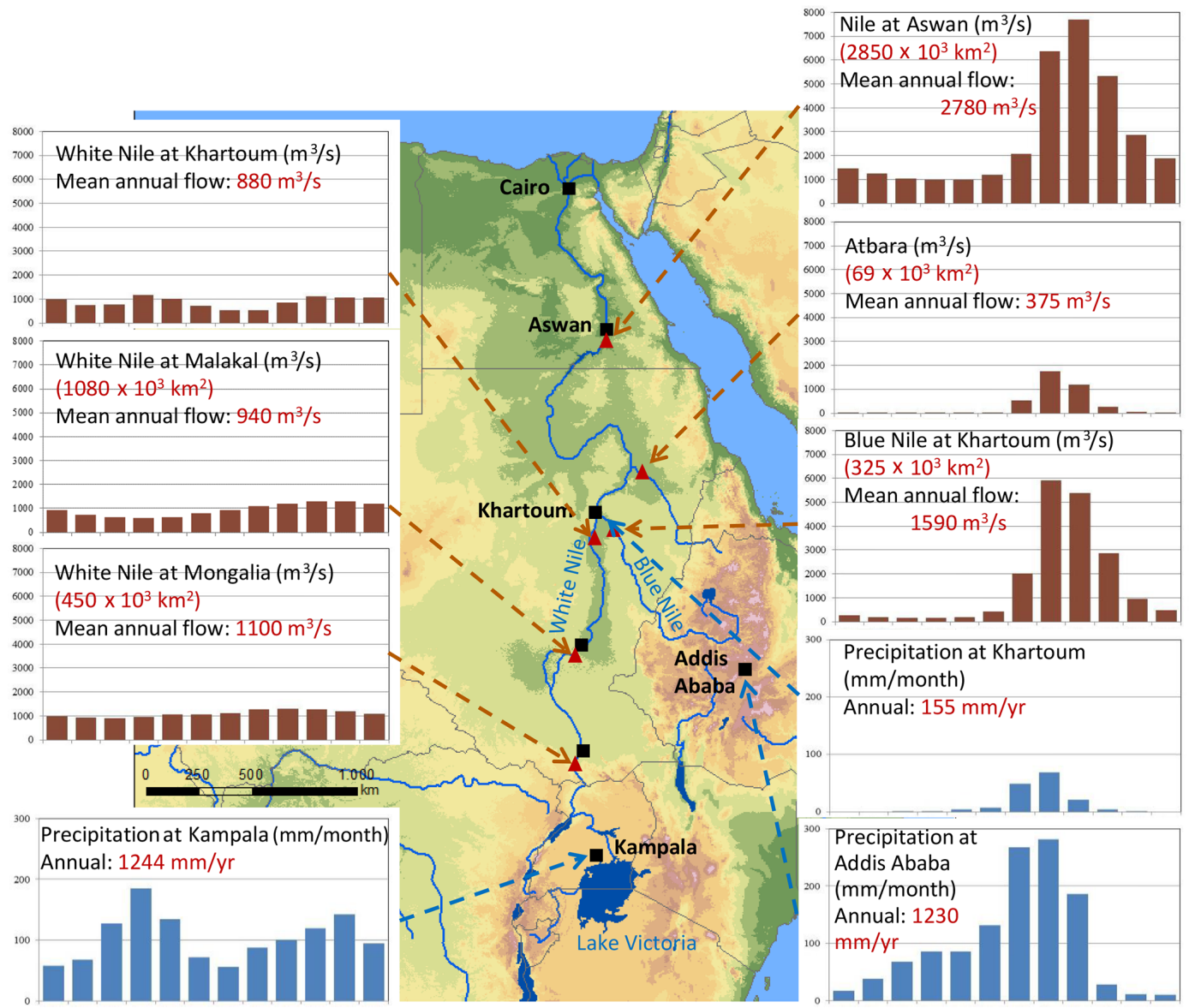

Figure 11. As in Fig. 9 but with additional modern information of precipitation and Nile flow (mean monthly values, January to December) at locations south of Aswan (Syene).

rain-storms that take place in that [area]. (John the Lydian, On the Months, 4, 107, English translation by Mischa Hooker; original: [OT30])

It is said that when continuous rains precipitate around Ethiopia during the summer and especially in its height; it is thus implied that it is because of them that the Nile increases. Indeed, this is how Poseidonius refers. (Cleomedes, De motu circulari corporum caelestium, 59, translation by the authors; original: [OT31])

A doxographer, the so-called Anonymus Florentinus, also wrote a short treatise in Greek (published with two alternative titles ${ }^{7}$ ) about the Nile's flow, which includes the following:

Callisthenes the historiographer objects those said a little while ago, supported by Anaxagoras and

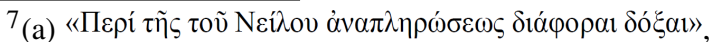

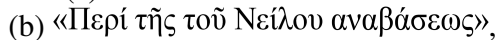

https://books.google.gr/books?id=i1IZAAAAYAAJ, last access: 30 March 2021.
Euripides. They say, presenting his own considered opinion, that from the rise of the Dog Star [beginning of July] up to the rise of Arcturus [midSeptember], in which time the monsoon winds blow, many showers occur in Ethiopia. These winds, they say, bring the clouds to Ethiopia. When the clouds strike against the mountains, huge quantities of water precipitate through which the Nile overflows. (Anonymus Florentinus on the Nile, translation by the authors; original: [OT32])

Furthermore, it appears that, during the Byzantine period, Aristotle's theory was confirmed by additional visits in the area. The Byzantine emperor Justinian sent an ambassador called Nonnosus (Nóvvoбos) to the king of the Axumites (in Ethiopia and parts of the Arabian Peninsula) around AD 530. He wrote an account of that visit, now lost, that was read and summarized by Photius in his Bibliotheca. Here is the relevant extract, in which it should be noted that the term "winter" is meant to denote the rainfall season:

When the sun enters Cancer, Leo, and Virgo, it is summer as far as Ave, as with us, and the atmo- 

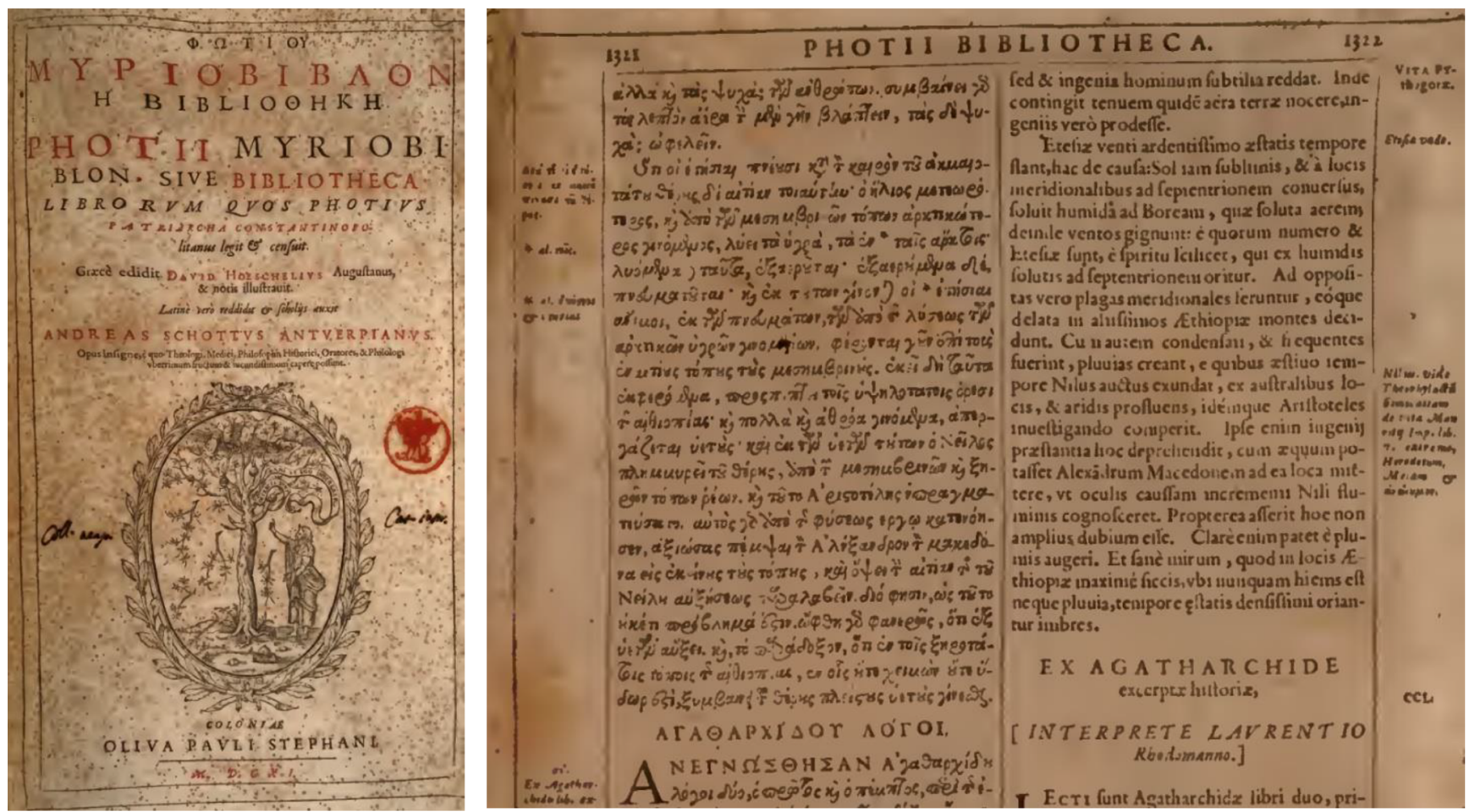

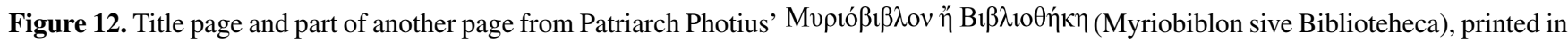
1611. The page depicted is that referring to the first scientific expedition in history, ordered by Aristotle and executed by his pupil Alexander the Great.

sphere is extremely dry; but from Ave to Axumis and the rest of Aethiopia, it is severe winter, not throughout the day, but beginning from midday, the sky being covered with clouds and the country flooded with violent rains. At that time also the Nile, spreading over Egypt, overflows and irrigates the land. But when the sun enters Capricornus, Aquarius, and Pisces, the atmosphere, conversely, floods the country of the Adulites as far as Ave, while it is summer from Ave to Axumis and the rest of Aethiopia, and the fruits of the earth are ripe. (Photius, 1611, on Nonnosus History, translated by John Henry Freese; original: [OT33])

Additional evidence is provided by Cosmas Indicopleustes

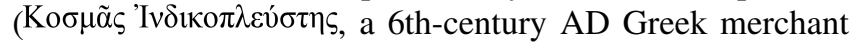
and traveller), who made several voyages to India during the reign of the emperor Justinian about which he wrote in his book Christian Topography.

In addition to these references in Greek, there is a treatise in Latin entitled Liber Aristotelis de Inundacione Nili (in short De Nilo), which is presumably a Latin translation of a lost text in Greek by Aristotle, whose Greek title should be $\Pi \varepsilon \rho i ̀ \tau \tilde{\eta} \varsigma \tau o \tilde{v} N \varepsilon i \lambda o v \dot{\alpha} v \alpha \beta \dot{\alpha} \sigma \varepsilon \omega \varsigma: 8$ The treatise was left out of

\footnotetext{
${ }^{8}$ It is referred to with this title in a comment on Aristotle's Meteorologica by pseudo-Alexander, contained in Rose (1886, p. 191).
}

the Corpus Aristotelicum and received little scholarly attention. However, Rose (1886) published the full Latin script of De Nilo, while an improved transcription thereof was recently published by Beullens (2014). There have also been translations of the work in two modern languages, French (Bonneau, 1971) and Dutch (Beullens, 2011). Some recent developments support the case that it is a translation of a genuine text by Aristotle or at least contains some portions of an original work by the philosopher (Beullens, 2014). The new evidence is (a) the publication of a papyrus (P. Oxy. 4458), which was shown to contain a short quotation from the original Greek text of De Nilo (Jakobi and Luppe, 2000) and (b) the observation that the quotation by Anonymus Florentinus almost literally follows the wording of De Nilo, if it is back-translated into Greek (Beullens, 2014).

De Nilo has the form of an Aristotelian problem, starting with the question to be solved:

How can it be explained that while other rivers swell in winter and become much smaller in summer, the Nile as the only river that flows into the sea, in the summer expands over a vast area and become so wide that only the villages stand out as islands? (Liber Aristotelis de Inundacione Nili, 1, translation by the authors based on Google translation of the Dutch text by Beullens, 2011; original: [OT34]) 


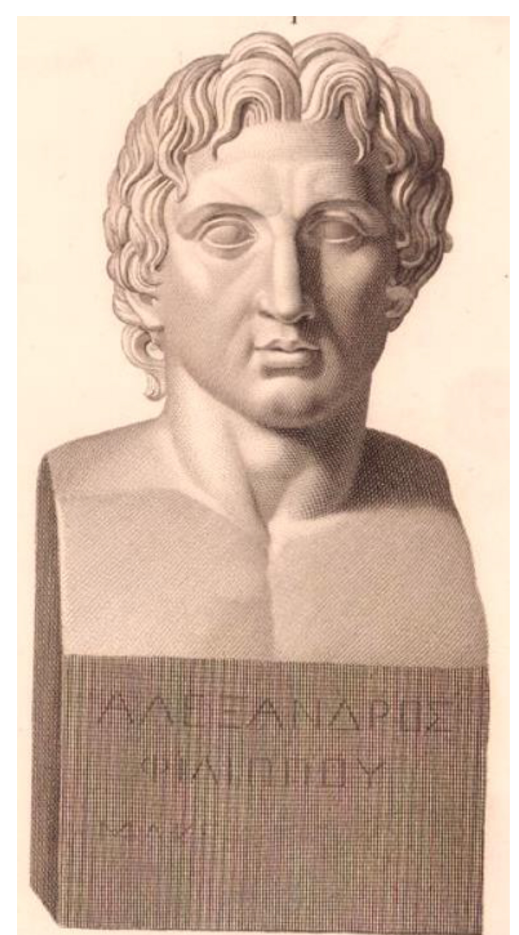

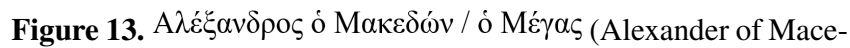
don/the Great; 356 BC-323 BC) (image source: Visconti, 1817).

The text continues with what we would today call a literature review, enumerating the explanations already given by other authors about the phenomenon (including those referred to by Herodotus) and then rejecting them one by one with logical arguments until there remains one, Aristotle's own theory, as precisely quoted by Anonymus Florentinus.

Overall, there is overwhelming evidence that Aristotle had resolved the paradox in scientific terms. However, it is relevant to ask the question how long it took for the scientific (and wider) community to assimilate and completely accept this scientific truth. The surprising answer to this question is 21 centuries.

Already from the 1 st century $\mathrm{BC}$, the following passage by Strabo indicates the reluctance to accept the explanation:

but the fact that the rising of the river results from rains should not have been investigated, nor yet should this matter have needed such witnesses as Poseidonius mentions; for instance, he says that it was Callisthenes who states that the summer rains are the cause of the risings, though $\mathrm{Cal}$ listhenes took the assertion from Aristotle, and Aristotle from Thrasyalces the Thasian (one of the early physicists), and Thrasyalces from someone else, and he from Homer, who calls the Nile "heaven-fed": "And back again to the land of Aegyptus, heaven-fed river." (Strabo, Geography,
17.1.5, translated by Horace Leonard Jones; original: [OT35])

Here we may remark that by attributing the explanation to Thrasyalces (an old natural philosopher, probably of the 5 th century BC, from the island of Thasos), Strabo devalues Aristotle's contribution, hiding the fact that, even if Thrasyalces had indeed made the same conjecture, there is a big difference as Aristotle verified the hypothesis by observation (ő $\psi \varepsilon l$ - by sight) through Alexander's expedition. Furthermore, Strabo seems to equate all explanations, eventually matching Aristotle's scientific one with Homer's mythical one.

And indeed, the mythical views are more charming and, hence, they continued to be popular during Roman times. The Roman Epicurean philosopher Lucretius (c. 99c. 55 BC) and the Stoic philosopher Seneca (4 BC-AD 65), both of whom wrote about the Nile, did not rely on Aristotle's scientific explanation. Rather, they were fascinated by the Nile for its mystery, not its demystification. An excellent summary of the reasons is contained in the following quotation by Merrills (2017):

The metaphysical qualities of the Nile - a river that replicated each year the origins of the world, and which overspilled its banks even into the bathhouses and taverns of Pompeii - were essential to its resonance in the Roman world.

The reference to Pompeii encapsulates the archaeological evidence of sacred objects and iconographies for the Nile and its waters.

And what about modern times? Were the mythical views abandoned after the first quantification of the hydrological cycle in the 17th century (Sect. 6)? This question is studied in detail in the Supplement, Sect. S2. In brief, the surprising answer is that a new mythology was developed around a "theory" of the "nitre", which was a mythical element that presumably caused the flooding of the Nile, while rainfall in Ethiopia had a minor role, if any. It took the visit to the origins of the Blue Nile by the Scottish traveller James Bruce and the publication of his book (Bruce, 1813) for the modern mythical theory to cease.

\section{Prominent scientists of the Hellenistic period with relevance to geosciences and hydrology}

The Hellenistic period, which starts with the death of Alexander in $323 \mathrm{BC}$ and ends with the emergence of the Roman Empire in $31 \mathrm{BC}$, was marked by the wide dissemination of Greek civilization and the flourishing of science. During this period several important scientific developments and breakthroughs occurred, some of which were not accepted as consensus theories for centuries. The reluctance to Aristotle's theory on the Nile is repeated in several other cases. 


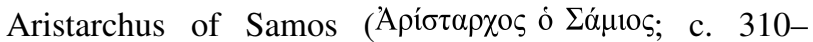
c. $230 \mathrm{BC}$; mathematician and astronomer) introduced the heliocentric model for the solar system 1800 years before Copernicus. He also said that the stars were distant suns and made calculations of the relative sizes of the Sun, Earth and Moon. Notably, before him the Pythagorean philosopher Philolaus (c. 470-c. 385 BC) had also moved the Earth from the centre of the cosmos and made it a planet, but in Philolaus' system Earth does not orbit the Sun but rather a central fire. Interestingly, Copernicus in the manuscript of his book De revolutionibus included a citation of Philolaus and Aristarchus, but he crossed it out before publication (Fig. 14). The point that was crossed out, translated in English (Gingerich, 1973, 1985), reads:

And if we should admit that the motion of the Sun and Moon could be demonstrated even if the Earth is fixed, then with respect to the other wandering bodies there is less agreement. It is credible that for these and similar causes (and not because of the reasons that Aristotle mentions and rejects), Philolaus believed in the mobility of the Earth and some even say that Aristarchus of Samos was of that opinion. But since such things could not be comprehended except by a keen intellect and continuing diligence, Plato does not conceal the fact that there were very few philosophers in that time who mastered the study of celestial motions.

While Aristarchus' ideas were contrary to the "consensus theory" for 1800 years, it is important to notice that they were adopted by Archimedes (c. 287-c. 212 BC), the leading scientist (mathematician, physicist, engineer, inventor and astronomer) of the Hellenistic world, who is regarded as perhaps the greatest mathematician of all time ${ }^{9}$. In fact, his treatise The Sand Reckoner provides the most valuable information about Aristarchus' ideas. Specifically, Archimedes writes that

It is hypothesized [by Aristarchus of Samos] that the fixed stars and the Sun remain unmoved and the Earth revolves about the Sun in the circumference of a circle, with the Sun lying in the middle of the orbit and the sphere of the fixed stars, situated about the same centre as the Sun, is so great that the circle in which the Earth is hypothesized to revolve, bears such a proportion to the distance of the fixed stars as the centre of the sphere bears to its surface. (Archimedes, The Sand Reckoner, I,

\footnotetext{
${ }^{9}$ This is illustrated by the fact that the Fields Medal (regarded as the highest honour for mathematicians) depicts Archimedes. The reader interested in the history of civilization may consider the fact that the head of Archimedes in the medal is synthesized by the imagination of the artist (Tropp, 1976), as there is no original depiction of him, neither in sculpture nor in coins (that is the reason we do not include any illustration of him in this paper).
}

translation by the authors based on I. Vardi; original: [OT36])

It has been speculated (Vardi, 1997) that Archimedes chose, among different cosmological theories, Aristarchus' for the single reason that it was the one yielding the largest size of the universe - as he wanted that size as large as possible for his construction of big numbers. However, we believe that a mind of the calibre of Archimedes would not choose a theory on this basis and certainly would not consider it if he thought it was erroneous.

It is well known that Archimedes offered several important contributions in mathematics, including the concept of infinitesimals and a first version of integral calculus. From the hydrological perspective, the principle named after him and the foundation of hydrostatics are important. Of his inventions the most relevant to hydrological engineering is Archimedes' screw, which is still in widespread use for pumping.

While some early Greek philosophers believed that the Earth is flat, Pythagoras and later Aristotle provided ar-

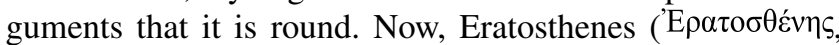
c. 276-c. 195/194 BC; a mathematician, geographer, poet, astronomer, and music theorist; head of the Library at Alexandria), among other achievements, calculated with remarkable accuracy $(<2.5 \%)$ the Earth's circumference by measuring, at the noon of the day of the summer solstice, the shadow cast by a gnomon at Alexandria and the distance between Alexandria and Syene, where the latter is situated close to the Tropic of Cancer. Eratosthenes also calculated, in following the windings of the Nile, the distances between several points on the Nile up to Meroe (Strabo, Geography, 17.1.2; Rawlins, 1982). Perhaps because of this, he has often been credited by several authors (including Koutsoyiannis, 2014) for solving the paradox of the Nile. However, in view of the information provided here (Sect. 4), his achievement seems to be no more than a further verification of Aristotle's theory. He also seems to have been aware of the earlier expedition to the Nile's sources for the purpose of proving Aristotle's theory (Burstein, 1976). Despite the advancements in geography during the Hellenistic period, the achieved geographical representation of the Earth was rather poor (Fig. 15).

Geography is also related to climatology and, through climate, to hydrology. The notion of climate was studied by Aristotle, who used another term, crasis ( $\kappa \tilde{\alpha} \sigma l \varsigma$ : mixture, blend). The term climate ( $\kappa \lambda i \mu \alpha, \mathrm{pl}$. $\kappa \lambda i \mu \alpha \tau \alpha)$ was introduced

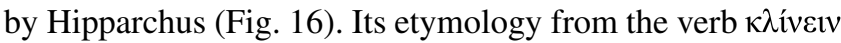
(to incline) expresses the dependence of climate on the seasonal pattern of inclination angles of the incoming sunbeams. Perhaps his most remarkable achievement is the discovery of the precession of the equinoxes, one of the cycles in Earth's motion, with a period of about 21000 years. This constitutes one of the several Milankovitch cycles, as they are called now, which determine the long-term changes in the climate. 


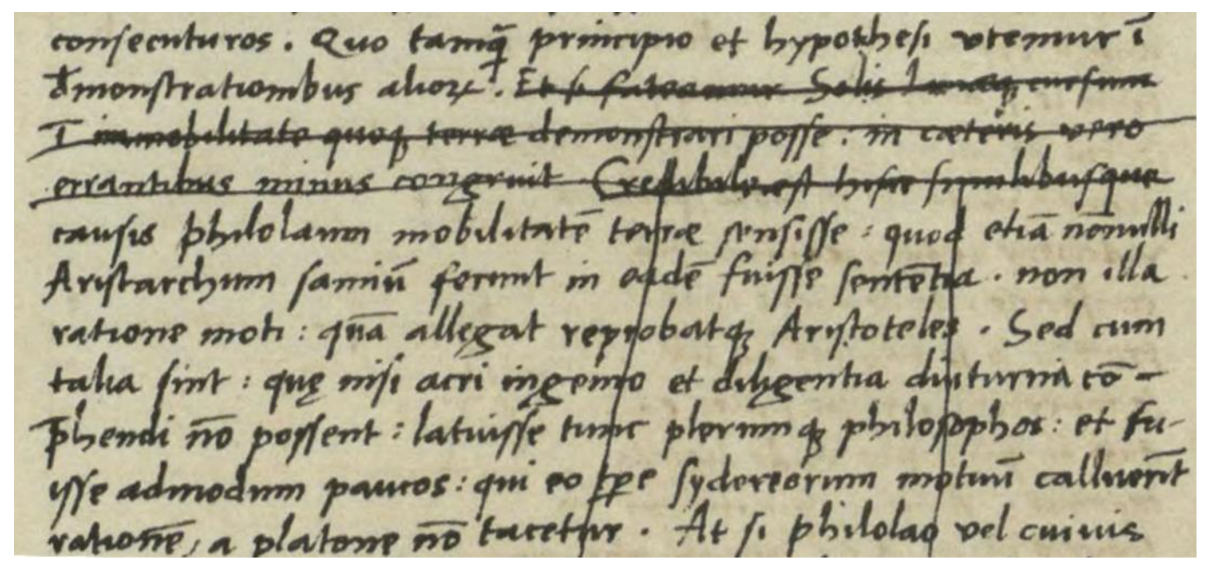

Figure 14. Part of page 22 of Book 1 of Copernicus' manuscript showing the references to Philolaus, Aristarchus and the Greek cosmology, which he crossed out before publication of his book De revolutionibus (source: http://copernicus.torun.pl/en/archives/De_revolutionibus/1/ ?view=gallery \&file=1\&page=22, last access: 30 March 2021).

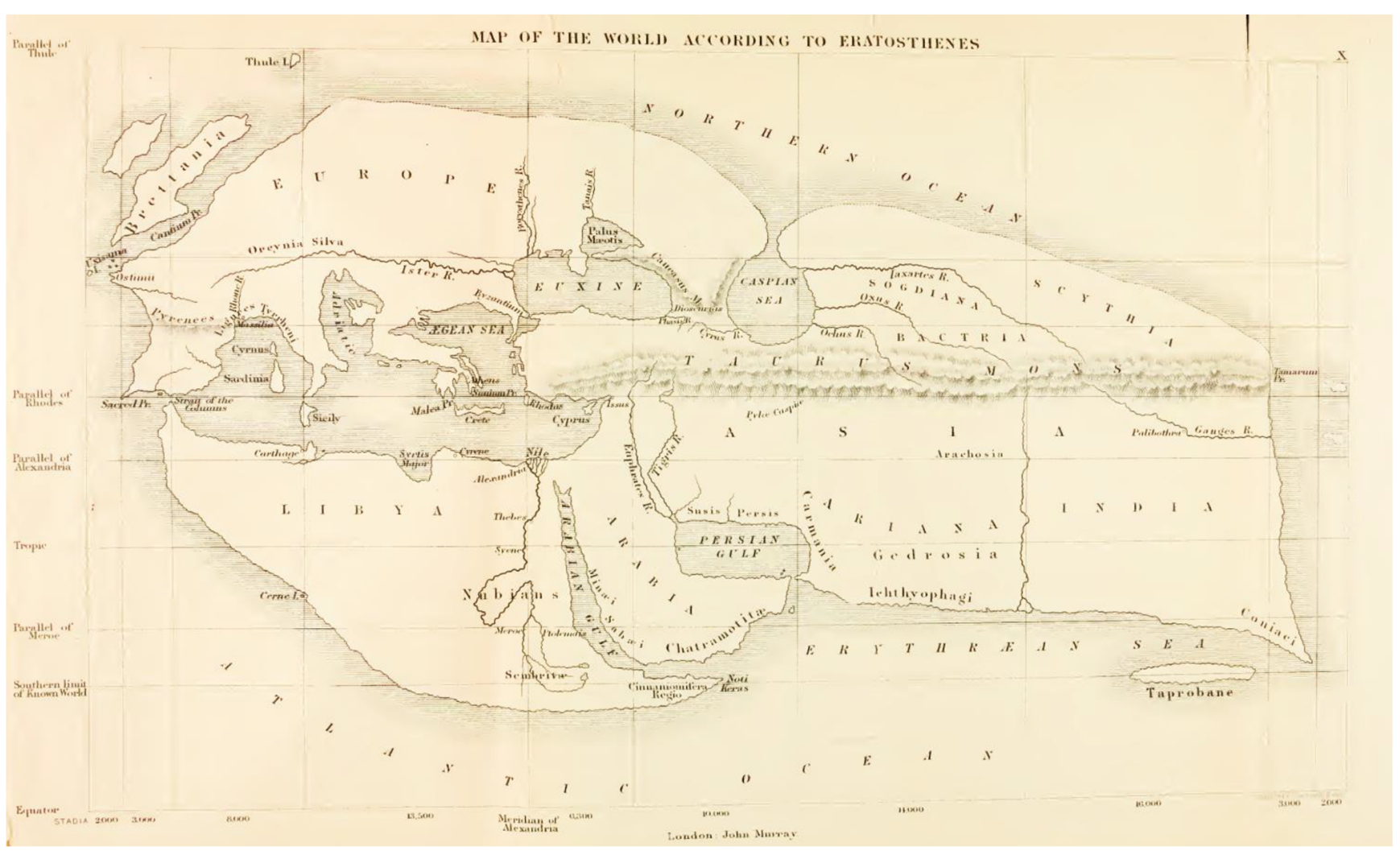

Figure 15. Map of the world according to Eratosthenes (reproduced from Bunbury, 1883).

The scientist of the Hellenistic period with the greatest contribution to hydrology was Heron (Hero) of Alexan-

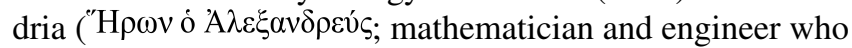
most likely lived in the 1st century BC or the 1st century $\mathrm{AD}$; see Woodcroft, 1851). He studied the notion of pressure and pneumatics and invented a steam machine. He introduced the term hydraulic (organ) for a musical instrument

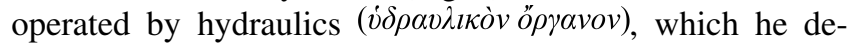

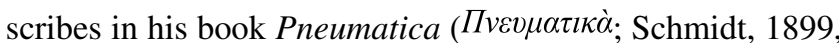

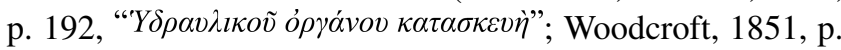
105). His contribution to hydrology is that he conceived the concept of flow discharge as the product, or at least the combination, of wet area and velocity, and described how to measure discharge with the volumetric method. Here is the relevant passage from his book Dioptra $(\Delta t o ́ \pi \tau \rho \alpha)$ : 


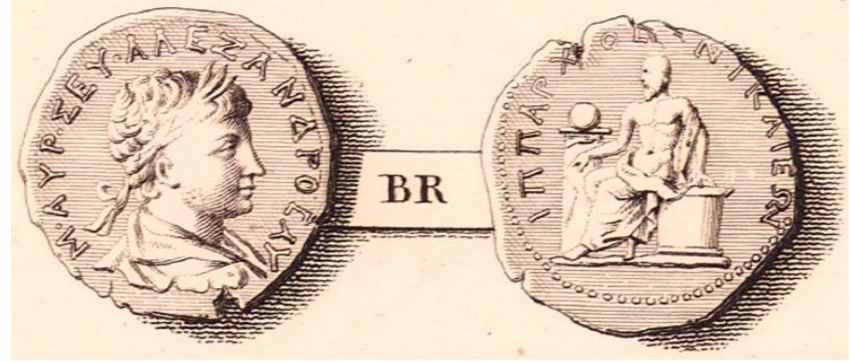

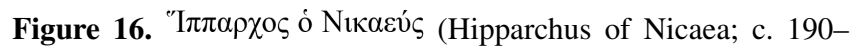
c. $120 \mathrm{BC})$, Greek astronomer, geographer and mathematician, founder of trigonometry and discoverer of the precession of the equinoxes. Hipparchus is depicted in the back facet of a coin whose front facet shows the Roman emperor Severus Alexander (M. AYP. $\Sigma E Y$. A $\Lambda$ E $\Xi A N \Delta P O \Sigma$ AY: Marcus Aurelius Alexandros Augustus) (image source: Visconti, 1817).

Given a spring, to determine its flow, that is, the quantity of water which it delivers. One must, however, note that the flow does not always remain the same. Thus, when there are rains the flow is increased, for the water on the hills being in excess is more violently squeezed out. But in times of dryness the flow subsides because no additional supply of water comes to the spring. In the case of the best springs, however, the amount of flow does not contract very much. Now it is necessary to block in all the water of the spring so that none of it runs of at any point, and to construct a lead pipe of rectangular cross section. Care should be taken to make the dimensions of the pipe considerably greater than those of the stream of water. The pipe should then be inserted at a place such that the water in the spring will flow out through it. That is, the pipe should be placed at a point below the spring so that it will receive the entire flow of water. Such a place below the spring will be determined by means of the dioptra. Now the water that flows through the pipe will cover a portion of the cross-section of the pipe at its mouth. Let this portion be, for example, 2 digits [in height]. Now suppose that the width of the opening of the pipe is 6 digits. $6 \times 2=12$. Thus, the flow of the spring is 12 [square] digits. It is to be noted that in order to know how much water the spring supplies it does not suffice to find the area of the cross section of the flow which in this case we say is 12 square digits. It is necessary also to find the speed of flow, for the swifter is the flow, the more water the spring supplies, and the slower it is, the less. One should therefore dig a reservoir under the stream and note with the help of a sundial how much water flows into the reservoir in a given time, and thus calcu- late how much will flow in a day. It is therefore unnecessary to measure the area of the cross section of the stream. For the amount of water delivered will be clear from the measure of the time. (Heron, Dioptra, 31, English translation by Cohen, 1958; original: [OT37])

In addition, the following passage from Heron's treatise Pneumatica is suggestive of his experimental method and the achieved understanding that air has mass and that wind is air in motion:

Vessels which seem to most men empty are not empty, as they suppose, but full of air. Now the air, as those who have treated of physics are agreed, is composed of particles minute and light, and for the most part invisible. If, then, we pour water into an apparently empty vessel, air will leave the vessel proportioned in quantity to the water which enters it. This may be seen from the following experiment. Let the vessel which seems to be empty be inverted, and, being carefully kept upright, pressed down into water; the water will not enter it even though it be entirely immersed: so that it is manifest that the air, being matter, and having itself filled all the space in the vessel, does not allow the water to enter. Now, if we bore the bottom of the vessel, the water will enter through the mouth, but the air will escape through the hole [...] Hence it must be assumed that the air is matter. The air when set in motion becomes wind (for wind is nothing else but air in motion), and if, when the bottom of the vessel has been pierced and the water is entering, we place the hand over the hole, we shall feel the wind escaping from the vessel. (Pneumatica, English translation by Woodcroft, 1851; original: [OT38])

In terms of the writing style seen in the original [OT38] (but not shown in the above translation, which is not faithful), we may observe that Heron uses second-person ("you") and third-person ("one") syntax, both in the active voice.

\section{From antiquity to modern science}

Modern hydrology owes a lot to several philosophers and scientists of the Renaissance, starting from the 15th century. Excellent accounts about this period can be found in several books and papers on the history of hydrology: Biswas (1970), Dooge (1959, 1974, 2003) and Wendland et al. (1998). A major breakthrough during the Renaissance was the recognition of the importance of the empirical basis in hydrological phenomena, acquired by observation, measurement and experiment. Leonardo da Vinci (1452-1519), the great artist, scientist and engineer, was also a great experimentalist and 
gave particular focus to water flow. This is testified by his book Del Moto e Misura dell' Acqua, written around 1500 (but published much later; da Vinci, 1828), and many of his manuscripts (see also Pfister et al., 2009). Benedetto Castelli (1578-1643), a student of Galileo and professor of mathematics at the universities of Rome and Pisa, also made measurements as seen from his book Della Misura dell' Acque Correnti (Castelli, 1628). There he explains how he installed a rain gauge in Perugia in order to provide a basis for estimating the variations in the level of Lake Trasimeno (Dooge, 2003) and controlling the discharge of its outlet. He also used floats to measure the stream velocity (Wendland et al., 1998).

One may notice the big chronological gap of about 15 centuries between the conception of flow discharge as a key concept of hydrometry by Heron of Alexandria and its rediscovery by Leonardo da Vinci and Benedetto Castelli.

Coming to the hydrological cycle, as already mentioned in the introduction and articulated in the above references, Pierre Perrault (1611-1680; Receiver General of Finances for Paris), Edme Mariotte (c. 1620-1684; French physicist and priest), Edmond Halley (1656-1742; English physicist, mathematician, astronomer, geophysicist and meteorologist) and John Dalton (1766-1844; English chemist, physicist, and meteorologist) were the pioneers of its quantification through measurement but not of the concept of the hydrological cycle per se, which is earlier. Indeed, Bernard Palissy (c. 1510c. 1589; French Huguenot potter, hydraulics engineer and craftsman) and several other scientists of the 16th century, whose lives and works are extensively reviewed by Biswas (1970), contributed in shedding light on the hydrological cycle. However, the concept is in fact centuries older, as documented in the previous sections.

Perrault's book is instructive in this respect, as the author puts his own work in the perspective of the old literature. Interestingly, he published his book anonymously in 1674 in French as well as an extended abstract in English (Anonymous, 1675), but a few years later the book was republished with his name (Perrault, 1678), while more recently a full translation in English appeared (Perrault, 1967). In its first part, constituting about half of the book, he critically reviews other philosophers, Ancient Greek (Plato, Aristotle, Epicurus), Roman (Vitruvius, Seneca, Pliny), medieval (Thomas Aquinas) and early modern (Scaliger, Cardano, Agricola, Dobrzenski, van Helmont, Lydiat, Davity, Descartes, Gassendi, François the Jesuit, Palissy and others). In particular, he appears to disagree with Vitruvius, Gassendi, François and Palissy, whose ideas he refers to as the Common Opinion (l'Opinion Commune). In the second part he presents his measurements, calculations and theories. Referring to the Seine River, his final result is this:

So that there needs but the sixth part of the Rain and Snow-water that falls in a year, to run continually through the whole year. (Anonymous, 1675)

Interestingly, Perrault also refers to the Nile as follows:
But when there would be countries where it never rains, that would not prevent rivers from flowing which would have their sources in other countries where it rains, as does the Nile which flows in Egypt where it does not rain. [...]

Continuation of the Author's opinion.

After having rejected the Common Opinion, after having shown that the water which flows in the Rivers for a year is not so considerable as Aristotle and those who followed him imagined, and that the rains can provide sufficient water to maintain their course for a year, it only remains for me to show how the waters of the rain and the snow that have fallen in the Rivers, can come out through the top of the mountains to make springs. (Perrault, 1678, p. 207, translation by the authors based on Google Translate; original: [OT39])

This is puzzling as in fact Aristotle's theory on the Nile was exactly this, i.e. that rainfall in another area (Ethiopia) was providing the water to sustain the flow (actually flood) of the Nile.

One interesting observation is that none of the celebrated publications of all these pioneers, namely da Vinci (1828), Palissy (1844), Castelli (1628), Perrault (1678), Mariotte (1700), Halley (1687) and Dalton (1802), contains the term hydrology. This raises the question of how and when this term appeared. The question is studied in full detail in the Supplement, Sect. S3, and the findings can be summarized in the following points.

- The term hydrology is Greek ( $\dot{\delta} \delta \rho o \lambda o y i \alpha$ from $v \delta \omega \rho$, water, and $\lambda o ́ \gamma o \varsigma$, reason) but not Ancient Greek.

- Most probably it appeared for the first time in its French variant, hydrologie, in 1614 in a book of medical and philosophical orientation (Landrey, 1614), following the Hippocratic approach on the relationship of water and health.

- It further appeared in other books of the 17th and 18th centuries, mostly in Latin but also in modern languages and mostly with medical and philosophical orientations, but also chemical, mineralogical and physical ones.

- At the end of the 18th century and during the 19th century, the domain covered by the term hydrology was expanded to include natural sciences (physics, meteorology, climatology), geography and hydraulics.

- At the end of the 19th century, an international congress of hydrology and climatology was held in Biarritz, France, in which hydrology was divided into two branches, medical hydrology and scientific hydrology; key persons of that congress were medical doctors, but there was also one explorer and geographer and one meteorologist. 
This explains why the International Association of Scientific Hydrology (IASH), which was established in 1922, adopted the term scientific hydrology, rather than simply hydrology, to distinguish itself from medical associations. The foundation of the IASH and its domain are described in the following extract from Lyons (1922), who writes about the first meeting of the International Union of Geodesy and Geophysics (IUGG) held in Rome in 1922:

the proposal had been made that an additional section should be formed to deal with the scientific problems which arise in various hydrological investigations, such as rivergauging, lake phenomena including seiches, run-off and evaporation, transport of material in suspension and in solution, glacier movement, etc. A committee examined the matter carefully and reported in favour of forming a Section of Scientific Hydrology. The recommendation was adopted by the General Assembly, which nominated Mr. B. H. Wade of the Physical Department, Cairo, as president, and Prof. G. Magrini as secretary.

Later, at the XV IUGG General Assembly in Moscow in 1971, the association replaced the term Scientific hydrology in its name with the unfortunate term Hydrological sciences (in the plural).

On the other hand, the branch of medical hydrology continued to exist but with declining activity. Today there still exist university departments (e.g. the Department of Medical Hydrology of the Complutense University of Madrid, 1912today $)^{10}$, as well as national and international organizations (e.g. the International Society of Medical Hydrology and Climatology ${ }^{11}$, each year convening in World Congresses ${ }^{12}$ yet not so populated and rich in activity as their "scientific" hydrological counterparts).

In the meantime, specifically in the 1960s, hydrology (without an adjective) acquired a clear definition as a science (UNESCO, 1963, 1964):

Hydrology is the science which deals with the waters of the earth, their occurrence, circulation and distribution on the planet, their physical and chemical properties and their interactions with the physical and biological environment, including their responses to human activity.

\footnotetext{
${ }^{10}$ In the University of Athens there existed a Chair of Clinical Hydrology and Climatotherapy (1938-1953), while the Greek Rheumatology Society had earlier been named the Greek Society of Rheumatology and Hydrology

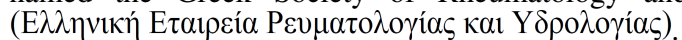

${ }^{11} \mathrm{http}: / /$ www.ismh-direct.net/info.aspx?sp=1, last access: 30 March 2021

${ }^{12} \mathrm{http} / / / \mathrm{www}$. ismh-direct.net/hirek.aspx?s=0\&archiv=1, last access: 30 March 2021
}

This definition complemented an earlier one by the US Ad Hoc Panel on Hydrology (1962), adding an essential element, the interaction of water with human activity. This definition, however, does not explicitly recognize the link of hydrology with hydraulic engineering (despite the fact that it was this very link that advanced it as a modern quantitative scientific discipline; Koutsoyiannis, 2014) nor with health issues (despite the facts exhibited above). It is probable that in the future such links would be reinstated, particularly after the importance given recently to health issues. However, those colleagues who may propose new sciences linking water with engineering or with health should be aware that such links are as old as Thales and Hippocrates.

\section{Epilogue}

Scientific theories are mostly wrong - in the sense that they are imperfect descriptions of reality, or approximations thereof. It is a matter of time for any theory to be replaced by one providing a better description or approximation. Naturally, most of the theories developed at the dawn of science (2600 years ago) have been replaced. This does not make them unscientific.

It is a good practice to study the history of science, recognize past contributions and give credit to those who made them. This necessitates consultation of original texts because interpretations by later authors, particularly of the works of the greatest minds, may distort the original meaning. And there is a lot of distortion, accompanied by remarkable arrogance, about the contribution of ancient scientists in geophysics - and hydrology in particular. Certainly, the ancient theories contain elements that are blatantly incorrect, according to modern knowledge, but these do not justify treating them with arrogance. Here we preferred to highlight the more correct elements which justify our respect and admiration.

The study of the history of the development of scientific ideas is useful as it reveals the effectiveness of thought and logic, which were the basic tools of ancient philosophers, in compiling a sensible world vision with some admirable elements, even though other elements are inconsistent according to modern knowledge. As the information provided here shows, in addition to thought and logic, observation, experimentation and measurement were all used by ancient philosophers, particularly by Aristotle and the scientists of the Hellenistic period.

As evident from present-day terminology (meteorology, climate, hydraulics), modern science is not independent of the ancient one. Advances in Greek antiquity were particularly seminal for modern science after the Renaissance. We believe that they can be seminal even for present-day science, serving again as an ideal - an ideal that, unfortunately, is no longer fully appreciated in modern academia. With this aim, we summarize the following important elements of the An- 
cient Greek philosophical framework that could be relevant in remedying modern weaknesses.

1. Posing scientific questions (e.g. the Nile paradox) and seeking scientific explanations was a crucial historical development, which did not prevail in earlier civilizations, as exemplified by Herodotus' contrast between Greek philosophers and Ancient Egyptian intellectuals (and priests).

2. Science and philosophy were not only invented, but also defined, with their meaning clarified as being the genuine pursuit of truth, independently of other (e.g. economic) interests.

3. Science, then called natural philosophy, was developed as a part of philosophy, with other parts thereof, i.e. metaphysics, epistemology, logic and axiology (ethics, aesthetics), being equally developed.

4. The development of (Aristotelian) logic offered a powerful instrument for science to distinguish sense from nonsense as well as deduction from induction and the relative validity of the inference based on each of these two methods.

5. The gradual development of the scientific method, which constitutes a part of philosophy, by incorporation of observation, experience and, at a later stage, experiment, provided a solid foundation for science.

6. Central to Ancient Greek thought was reasoning as the main tool for the search for truth. By no means does this imply that the philosophers of Ancient Greece tended to distrust observations, as incorrectly asserted by some modern scholars (where samples are given in the introduction). Obviously, if this happened, it would contradict reasoning per se (it is totally unreasonable to dismiss observations).

7. Clarity $(\sigma \alpha \varphi \eta ́ v \varepsilon \imath \alpha)$ was also a desideratum so strong that Aristotle identified it with truth. This is also related to the accurate accounting of the phenomena and the attainment of accurate scientific knowledge (Lesher, 2010). The introduction of terminology, i.e. of sophisticated terms whose meaning may not be identical to the colloquial one, and their definitions is another reflection of the clarity desideratum.

8. Formulation of a plurality of ideas by different scholars, as well as their debate, were vital for the development of science. It is clear from the quotations given above that Ancient Greek scholars cited and discussed each other's ideas and theories, mostly with proper respect and sometimes with moderate irony. Thanks to these discussions, today we are aware of opinions of philosophers whose original works are totally lost.
9. The plurality of ideas and diversity of opinions, some of which necessarily were better than others, resulted in an evolutionary process which in turn enabled scientific progress. It appears that such recently promoted ideas as that of a "settled science" did not have a place in the ancient environment of scientific inquiry.

10. An important development that expedited scientific progress was the creation of philosophical schools, functioning as centres of higher-level education and research, similar to modern universities. Plato's Academy, Aristotle's Lyceum (or Peripatetic School), Epicurus' Kepos (meaning garden), and Zeno's Stoa (meaning arcade) were some of the most famous. After 9 centuries of continuous operation, they were massively closed in AD 529 by an infamous edict by the emperor Justinian, which marked a societal paradigm shift and a millennium-long regression in scientific inquiry.

11. The communication of ideas among philosophers and to the public was organized in the form of books. Within this practice, a writing style or code was developed, characterized by a critical literature review and expression of the author's own thoughts, using a sophisticated language. This writing style is more or less followed even in the present day, as can be inferred by inspecting several extracts from Ancient Greek texts given above.

12. According to Plato and Aristotle, the motivation of philosophers is their curiosity to explain nature, but according to Herodotus [OT22], it is their ambition to achieve a reputation for wisdom. Noting that even this latter does not look like an unethical incentive, we may assert that the development of science complies with the development of axiology and of ethical values, including the promotion of the truth as an ethical value and the modesty of those seeking it. Even the term philosophy ( Notably, the term philosopher ( $\varphi \lambda$ ó $\sigma o \varphi \circ \varsigma)$ replaced the

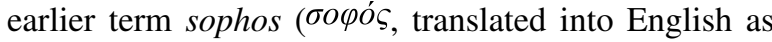
sage or wise, as in the expression "Seven Sages"; see Sect. 2). According to a Heraclitian aphorism, wise is

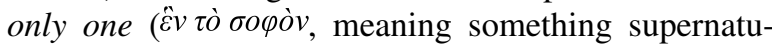
ral, i.e. God), and henceforth Pythagoras introduced the term philosopher, meaning lover (or friend) of wisdom ( $\varphi$ i $\lambda \circ \varsigma \sigma o \varphi i \alpha \varsigma)$. This is clarified in the following quotation:

Pythagoras was the first to name it philosophy and himself a philosopher [...] for no man is wise, but God alone. (Diogenes Laertius, Lives of the Philosophers, 1.12; original: [OT40])

The above points offer today's scientists powerful lessons, profoundly relevant in our times. First - and with reference to point $2-$ it is useful to bear in mind that, in accordance 
with Plato's definition quoted in the introduction, scientists are "lovers of the vision of truth". The importance of seeking the truth is also highlighted by Aristotle in the following quotations:

Socrates is dear [friend], but truth is dearest. (Ammonius, Life of Aristotle; original: [OT41])

Still perhaps it would appear desirable, and indeed it would seem to be obligatory, especially for a philosopher, to sacrifice even one's closest personal ties in defense of the truth. Both are dear to us, yet it is our duty to prefer the truth. (Aristotle, Nicomachean Ethics 1096a11; original: [OT42])

Arguably, this ancient ideal is forgotten in modern science, where research depends on funds in directions that are prescribed by economic or political interests and where academic careers depend on success in attracting such funds. Mixing of science with politics and economic interests has been promoted by many as a positive development, but in our opinion this is a negative development that only promises decadence. One may recall that Plato, Aristotle and other Greek philosophers, while clarifying the meaning of science and philosophy, used different terms for knowledge driven by political and economic interests and those seeking it, i.e.

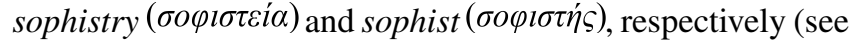
also Taylor, 1919; Horrigan, 2007; Papastephanou, 2015; Koutsoyiannis, 2021).

Regression in modern science also appears with respect to points 3-5. While the tradition has remained that the highest degree in education be called Philosophy Doctor, or $\mathrm{PhD}$, little "Ph" (if at all) is actually contained in doctoral research, and most PhD students are not aware of the philosophical premises of the scientific method (cf. Gauch, 2003). Furthermore, with reference to point 7 , clarity may have ceased to be a desideratum, a development possibly influenced by politics. And finally, with reference to points 8-9, while diversity is currently promoted in several societal functions, diversity of opinion on scientific issues is often discouraged, and scientific debate on some sensitive issues is virtually prohibited.

An additional lesson, perhaps not obvious from our discourse, is that it takes courage to formulate scientific theories - now as well as then. A relevant extract is the following, by Plutarch.

The first man to put in writing, most clearly and most courageously of all, the explanation of the moon's illumination and darkness, was Anaxagoras. But he was no ancient authority, nor was his account in high repute. It was still under seal of secrecy, and made its way slowly among a few only, who received it with a certain caution rather than with confidence. For people did not tolerate the natural philosophers and stargazers, as they were then called, because they reduced the divine agency down to unreasoning causes, blind forces, and necessary incidents. Even Protagoras was exiled, Anaxagoras was imprisoned and with difficulty rescued by Pericles, and Socrates, though he had nothing whatever to do with such matters, nevertheless lost his life because of philosophy. (Plutarch, Nicias, 23; translation by Immanuel Velikovsky in Anaxagoras $^{13}$; original: [OT43])

Note that Anaxagoras was charged of impiety and was sentenced to death by the Athenian court. He avoided this penalty by leaving Athens, and he spent his remaining years in exile. From Plutarch's information we may infer that Anaxagoras enjoyed the gratitude of his pupil Pericles. Similar is the relationship of Aristotle and his pupil Alexander the Great. This, however, does not happen all the time in history. (A remarkable modern counterexample is the contribution of Andrey Kolmogorov, Pavel Alexandrov and other students of Nikolai Luzin in convicting their mentor likely to death an attempt which was prevented by the intervention of Pyotr Kapitsa and ultimately by a decision by Stalin; Graham and Kantor, 2009). On the other hand, Socrates, even though he too had prominent pupils like Plato and Xenophon, paid off with his life the political actions that brought calamity to Athens by some of his other pupils, such as Critias and Alcibiades. Examples of prominent scientists who also lost their lives for their ideas in later periods are the Greek (female) astronomer, mathematician and philosopher Hypatia (c. AD 360-415) and the Italian astronomer, physicist and engineer Giordano Bruno (1548-1600). A counterexample is Galileo Galilei (1564-1642), who, despite publicly expressing his revolutionary scientific ideas that triggered the establishment's hostility, was able to save his life. Bertolt Brecht also taught a lesson about this non-heroic path in his story "Maßnahmen gegen die Gewalt" (Measures against Authority; Fothergill, 2007).

Courage is a necessary condition for formulating scientific theories, but it does not suffice for the acceptance of the theories, even if they are correct. Not even authority is a sufficient condition. Certainly, the dilemma posed by Russell, observation vs. authority (see the introduction), which we prefer to reformulate as scientific truth vs. authority, is relevant. Undoubtedly, the opposition between science and authority is important in order to interpret the history of science. However, the above discourse points to another characteristic dilemma, scientific truth vs. public acceptance, where scientists are not to be excluded from the public. This is both diachronic and also very modern. The case of Aristotle's correct theory on the Nile flooding, which was also confirmed by observation through the first scientific expedition in history, is the most characteristic. Neither the fact that Aristotle was an authority nor the backing of the theory by observation helped acceptance of the theory. Aristarchus' heliocen-

\footnotetext{
${ }^{13} \mathrm{http} / / / \mathrm{www}$. varchive.org/ce/orbit/anax.htm, last access: 30 March 2021. Note that Immanuel Velikovsky also experienced extreme hostility from 20th century scholars for his ideas.
} 
tric model is another similar case. Both scientific theories were kept hidden or rejected for centuries. Mythology has been more popular than science, not only in ancient times, but also in modern ones (cf. the "nitre theory" on the Nile flooding).

As implied in several of the modern-day quotations given in the introduction, the authority of important ancient philosophers such as Plato and Aristotle has been regarded as an obstacle to subsequent scientific progress because of the tendency of later philosophers to accept their opinions almost without question. However, the spectacular scientific progress during the Hellenistic period and the above example of aversion to Aristotle's explanation of the Nile flows clearly refute such claims. We believe that it is the intellectual decadence, accompanied by the closure of the philosophical schools in the sixth century AD, that led to regression not the preceding giants who offered their shoulders for the next generations to stand on. Signs of similar decadence are also present in our era, particularly in the Western World, where ideas are being replaced by ideologies and reason by stereotypes of "correctness". Hopefully this is less the case in the Eastern World. As the Earth is round, the very terms "Western" and "Eastern" presuppose some reference point and this is Greece. We, thus, believe that revisiting the values developed in Greek antiquity is a proper measure against modern decadence.

Data availability. The classical texts of Greek antiquity are contained in several archives, among which we highlight (a) original Ancient Greek texts with translations in modern Greek at the Centre for the Greek Language (project Portal for the Greek language and language education) http://www.greek-language.gr/ digitalResources/ancient_greek/library/index.html (last access: 30 March 2021), (b) original Ancient Greek texts without translation by Greek Wikisource (Vikithiki) the free library of Greek texts, https://el.wikisource.org/wiki/ (last access: 30 March 2021) and (c) Ancient Greek and Latin texts with translations in English by the Tufts University (Perseus Digital Library Project, Perseus Collection - Greek and Roman Materials) http://www.perseus.tufts.edu/hopper/collection?collection= Perseus:collection:Greco-Roman (last access: 30 March 2021) (also linked at https://topostext.org/all-texts.php, last access: 30 March 2021). Here, unless otherwise specified, source (c) has been used. The most comprehensive Ancient Greek lexicon, known as LiddellScott-Jones (LSJ), is in the public domain at https://lsj.gr/ (last access: 30 March 2021). Old books are made available in the public domain by the Internet Archive, a non-profit library of free books, movies, software, music, websites, and more, at https:// archive.org/details/texts (last access: 30 March 2021), which contains 28 million books with entries going back to the beginning of typography. Unless otherwise specified in the list of references, this was the source of the old books perused here. The iconographies used in the paper have been taken from engravings by Visconti (1817), which are available in the public domain at https: //archive.org/details/gri_33125010850713/ (last access: 30 March 2021) and https://arachne.dainst.org/entity/1884649 (last access: 30
March 2021). The accompanying three-volume publication by Visconti (1824-1826) provides information on the origin of the depiction and explanations why these are likely original, taken from sculptures and coins. An older publication with some depictions is the book by Thevet (1584), but these depictions are not necessarily original. In a later publication by Wallis (1894), most depictions seem to be redrawings of those in Visconti (1817). All these are in public domain and are currently reproduced in common platforms such as Wikipedia. The depictions in Raphael's School of Athens (https://en.wikipedia.org/wiki/The_School_of_Athens, last access: 30 March 2021) are also commonly used, but they do not necessarily correspond to the original faces as Raphael used several models, including himself.

Supplement. The supplement related to this article is available online at: https://doi.org/10.5194/hess-25-2419-2021-supplement.

Author contributions. DK and NM have collaborated on this research and exchanged ideas and information for many years. DK has made the most of the investigation of ancient and modern sources and wrote most of the paper. NM has studied the texts by Herodotus and constructed the graphs visualizing in modern terms the ancient information. Both authors have reviewed the text and agreed to the published version of the paper.

Competing interests. The authors declare that they have no conflict of interest.

Special issue statement. This article is part of the special issue "History of hydrology" (HESS/HGSS inter-journal SI). It is not associated with a conference.

Acknowledgements. We thank Okke Batelaan, Keith Beven, Laurent Pfister and Roberto Ranzi, organizers of the EGU 2018 session HS1.8, History of Hydrology (and editors of the special issue together with Chantal Gascuel), for their invitation which motivated this research. We also thank the reviewer Matteo Settura and an anonymous reviewer for their encouraging and very constructive comments, which helped us to substantially improve the paper. We appreciate personal discussions, comments and corrections on the manuscript by John Ding, Lei Ye, Marcia Wyatt and Vassilios Zoukos. We received no funding for this research but conducted it for scientific curiosity.

Review statement. This paper was edited by Roberto Ranzi and reviewed by Matteo Settura and one anonymous referee.

\section{References}

Anonymous: A particular account, given by an anonymous French author in his hook of the origin of fountains, printed 1674 at 
Paris, to shew that the rain and snow waters are sufficient to make fountains and rivers run perpetually, Philosophical Transactions, 10, 447-450, available at: https://archive.org/details/ philosophicaltra1016roya (last access: 30 March 2021), 1675.

Beullens, P.: De overstroming van de Nijl, Een vergeten traktaat van Aristoteles?, Tijdschr. Filos., 73, 13-534, https://doi.org/10.2143/TVF.73.3.2131119, 2011.

Beullens, P.: Facilius sit Nili caput invenire: Towards an attribution and reconstruction of the Aristotelian treatise De inundatione Nili, in: Translating at the Court: Bartholomew of Messina and Cultural Life at the Court of Manfred, King of Sicily, Vol. 45, 303-329, available at: https://lirias.kuleuven.be/retrieve/293331 (last access: 30 March 2021), 2014.

Biswas, A. K.: History of Hydrology, North-Holland, Amsterdam, American Elsevier, New York, 366 pp., available at: https: //archive.org/details/historyofhydrolo0000bisw/ (last access: 30 March 2021), 1970.

Bonneau, D.: Liber Aristotelis de inundatione Nili - texte - traduction - étude, Études de Papyrologie, 9, 1-33, 1971.

Bunbury, E. H.: A History of Ancient Geography Among the Greeks and Romans, From the Earliest Ages till the Fall of The Roman Empire, Murray, London, 2nd ed., 666 pp., available at: https://archive.org/details/historyofancient00bunb/ (last access: 30 March 2021), 1883.

Bruce, J.: Travels to discover the source of the Nile, in the years 1768,1769 , 1771, 1772, and 1773, Gregg International Westmead, Eng., 3rd edition, 535 pp., available at: https://archive.org/ details/travelstodiscov03brucgoog/ (last access: 30 March 2021), 1813.

Burstein, S. M.: Alexander, Callisthenes and the Sources of the Nile, Greek, Roman and Byzantine Studies, 17, 135-146, 1976.

Castelli, B.: Della Misura dell' Acque Correnti, Stamparia Camerale, 46 pp., available at: https://archive.org/details/bub_gb_ 0CquMDOfdUoC (last access: 30 March 2021), 1628.

Cohen, M. R.: A source book in Greek science, Harvard University Press, Cambridge, 616 pp., available at: https://archive. org/details/sourcebookingree0000cohe/ (last access: 30 March 2021), 1958.

Dalton, J.: Experiments and observations to determine whether the quantity of rain and dew is equal to the quantity of water carried off by the rivers and raised by evaporation: With an enquiry into the origin of springs, Memoirs of the Manchester Society, 5, part 2, 65-67, available at: https://books.google.gr/books?id= nYgCAAAAYAAJ (last access: 30 March 2021), 1802.

da Vinci, L.: Del Moto e Misura dell' Acqua, Francesco Cardinali, Bologna, 310 pp., available at: https://books.google.gr/books? id=zIJUPEYiLt8C (last access: 30 March 2021), 1828.

Dooge, J. C. I.: Un bilan hydrologique au XVIIe siècle [Quantitative hydrology in the 17th century], La Houille Blanche, 6, 799-807, 1959.

Dooge, J. C. I.: The development of hydrological concepts in Britain and Ireland between 1674 and 1874, Hydrol. Sci. B., 19, 279302, https://doi.org/10.1080/02626667409493917, 1974.

Dooge, J. C. I.: Background to modern hydrology, The basis of civilization - water science, in: Proceedings of the UNESCO/IAHS /IWHA Symposium held in Rome, December 2003, IAHS Publ., Wallingford, UK, 286, 3-12, 2003.
Driessen, A: Aristotle and the foundation of quantum mechanics, philsci-archive, available at: http://philsci-archive.pitt.edu/ 16265/ (last access: 30 March 2021), 2019.

Forbes, R. J.: A Short History of the Art of Distillation, Brill, Leiden, Netherlands, 405 pp., 1970.

Fothergill, A.: Bertolt Brecht's "Measures against Authority", Stud. Theatr. Perform., 27, 169-170, 2007.

Gauch Jr., H. G.: Scientific Method in Practice, Cambridge University Press, Cambridge, UK, 2003.

Gingerich, O.: From Copernicus to Kepler: heliocentrism as model and reality, P. Am. Philos. Soc., cxvii, 513-522, 1973.

Gingerich, O.: Did Copernicus owe a debt to Aristarchus?, J. Hist. Astron., 16, 37-42, 1985.

Graham, L. and Kantor, J.-M.: Naming Infinity: A True Story of Religious Mysticism and Mathematical Creativity, Harvard University Press, Cambridge, Massachusetts, USA, 2009.

Halley, E.: An estimate of the quantity of vapour raised out of the sea by the warmth of the sun; derived from an experiment shown before the Royal Society, at one of their late meetings, Phil. Trans. R. Soc., 16, 366-370, https://doi.org/10.1098/rstl.1686.0067, 1687.

Heisenberg, W.: The development of the interpretation of the quantum theory, in: Niels Bohr and the Development of Physics, Essays dedicated to Niels Bohr on the occasion of his seventieth birthday, edited by: Pauli, W., 2nd edition, Pergamon Press, New York, 12-29, available at: https://archive.org/details/ nielsbohrdevelop0000paul/ (last access: 30 March 2021), 1962.

Horrigan, P. G.: Epistemology: An Introduction to the Philosophy of Knowledge; iUniverse, New York, NY, USA, available at: http://books.google.gr/books?id=ZcF76pdhha8C (last access: 2 February 2021), 2007.

Jaeger, G.: Quantum potentiality revisited, Phil. Trans. R. Soc. A, 375, 20160390, https://doi.org/10.1098/rsta.2016.0390, 2017.

Jaeger, G.: Developments in quantum probability and the Copenhagen approach, Entropy, 20, 420, https://doi.org/10.3390/e20060420, 2018.

Jakobi, R. and Luppe, W.: P. Oxy. 4458 col. I: Aristoteles redivivus, Zeitschrift für Papyrologie und Epigraphik, 131, 15-18, 2000.

Kastner, R. E., Kauffman, S., and Epperson, M.: Taking Heisenberg's potentia seriously, International Journal of Quantum Foundations, 4, 158-172, 2018.

Katsifarakis, K. L. and Avgoloupis, I.: A new approach to the description of a Babylonian hydraulic work by Herodotus, Classical Quart., 63, 888-891, 2013.

Katsifarakis, K. L. and Avgoloupis, I.: References of Herodotus to hydrology, hydraulics and hydraulic works, Proc. of Int. Conf. "Water and Civilization: Exploring water history in the horizon of the community of shared future for mankind", Wuhan, China, 9-12 May 2019.

Klemeš, V.: Dilettantism in hydrology: transition or destiny?, Water Resour. Res., 22, 177S-188S, https://doi.org/10.1029/WR022i09Sp0177S, 1986.

Koutsoyiannis, D.: Reconciling hydrology with engineering, Hydrol. Res., 45, 2-22, https://doi.org/10.2166/nh.2013.092, 2014.

Koutsoyiannis, D.: Rethinking climate, climate change, and their relationship with water, Water, 13, 849, https://doi.org/10.3390/w13060849, 2021. 
Koutsoyiannis, D., Mamassis, N., and Tegos, A.: Logical and illogical exegeses of hydrometeorological phenomena in ancient Greece, Water Sci. Tech.-W. Sup., 7, 13-22, 2007.

Koutsoyiannis, D., Mamassis, N., Efstratiadis, A., Zarkadoulas, N., and Markonis, Y.: Floods in Greece, in: Changes of Flood Risk in Europe, edited by: Kundzewicz, Z. W., chapter 12, 238-256, IAHS Press, Wallingford, 2012.

Landrey, J.: Hydrologie ou Discours de l'Eaue, Orléans par Fabian Hotot, Paris, available at: https://archive.org/details/BIUSante_ 30326, https://babel.hathitrust.org/cgi/pt?id=ucm.5327265665 (last access: 30 March 2021), 1614.

Lee, H. D. P. (translator): Aristotle, VII, Meteorologica, Harvard University Press, Cambridge, available at: https://archive. org/details/meteorologica0007aris (last access: 28 March 2021), 1952.

Lesher, J. H.: Saphêneia in Aristotle: "Clarity", "Precision", and "Knowledge", Apeiron, 43, 143-156, 2010.

Lyons, H. G.: The International Union of Geodesy and Geophysics, Nature, 109, 758-759, 1922

Mariotte, M.: Traité du Mouvement des Eaux et des Autres Corps Fluides, Jean Jombert, Paris, 427 pp., available at: https://archive. org/details/traitdumouvemen00marigoog (last access: 30 March 2021), 1700.

Merrills, A.: Roman Geographies of the Nile: From the Late Republic to the Early Empire, Cambridge University Press, Cambridge, UK, 2017.

Montanari, A., Young, G., Savenije, H. H. G., Hughes, D., Wagener, T., Ren, L .L., Koutsoyiannis, D., Cudennec, C., Toth, E., Grimaldi, S., Blöschl, G., Sivapalan, M., Beven, K., Gupta, H., Hipsey, M., Schaefli, B., Arheimer, B., Boegh, E., Schymanski, S. J., Di Baldassarre, G., Yu, B., Hubert, P., Huang, Y., Schumann, A., Post, D., Srinivasan, V., Harman, C., Thompson, S., Rogger, M., Viglione, A., McMillan, H., Characklis, G., Pang, Z., and Belyaev, V.: "Panta Rhei - Everything Flows", Change in Hydrology and Society - The IAHS Scientific Decade 2013-2022, Hydrolog. Sci. J., 58, 1256-1275, https://doi.org/10.1080/02626667.2013.809088, 2013.

Morewood, S.: A Philosophical and Statistical History of the Inventions and Customs of Ancient and Modern Nations in the Manufacture and Use of Inebriating Liquors: with the Present Practice of Distillation in All Its Varieties: Together with an Extensive Illustration of the Consumption and Effects of Opium, and Other Stimulants Used in the East, as Substitutes for Wine and Spirits, W. Curry, Jun. \& Co., W. Carson, Dublin, 778 pp., available at: https://archive.org/details/philosophicalsta00morerich (last access: 30 March 2021), 1838.

Palissy, B.: Oeuvres Complètes de Bernard Palissy, J. J. Dubochet, Paris, 494 pp., available at: https://archive.org/details/ uvrescompltesd00pali (last access: 30 March 2021), 1844.

Papastephanou, M.: The 'lifeblood' of science and its politics: Interrogating epistemic curiosity as an educational aim, Educ. Sci., 6, 1-16, https://doi.org/10.3390/educsci6010001, 2015.

Perrault, P.: On the Origin of Springs, transl. by La Rocque, A., Hafner Publishing Co., New York, 1967.

Perrault, P.: De l'Origine des Fontaines, Chez Jean \& Laurent d'Houry, Paris, 288 pp., available at: https://archive.org/details/ deloriginedesfon00perr (last access: 30 March 2021), 1678.
Pfister, L., Savenije, H. H. G., and Fenicia, F.: Leonardo da Vinci's Water Theory, IAHS Special Publication no. 9, IAHS Press, Wallingford, 2009.

Photius: Myriobiblon sive Biblioteheca

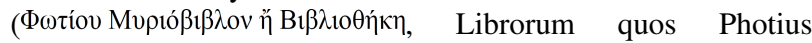
Patriarcha Constantinapolitanus Legit \& Censuit), Oliua Pauli Stephani, Colonia (Cologne), available at: https://archive.org/details/bub_gb_7aff8OLv0T8C (Greek original and translation in Latin), Greek original and French translation available at: http://remacle.org/bloodwolf/erudits/photius/, English translation of parts available at: http://www.tertullian. org/fathers/photius_01toc.htm (last access: 30 March 2021), 1611.

Popper, K.: Quantum Physics and the Schism in Physics, Unwin Hyman, London, 229 pp., 1982.

Price, M.: Introducing Groundwater, 2nd Edn., Chapman \& Hall, London, 1996

Rawlins, D.: The Eratosthenes-Strabo Nile Map: Is It the earliest surviving instance of spherical cartography? Did it supply the 5000 stades arc for Eratosthenes' experiment?, Arch. Hist. Exact. Sci., 26, 211-219, 1982.

Rosbjerg, D. and Rodda, J.: IAHS: a brief history of hydrology, Hist. Geo Space. Sci., 10, 109-118, https://doi.org/10.5194/hgss10-109-2019, 2019.

Rose, V.: Aristotelis quoe Ferebantur Librorum Fragmenta, In Aedibus B.G. Teubneri, Lipsiae, 463 pp., available at: https://archive. org/details/bub_gb_5S0BAAAAMAAJ (last access: 30 March 2021), 1886

Russell, B.: The Impact of Science on Society, Columbia University Press, New York, 64 pp., available at: https://archive.org/ details/TheImpactOfScienceOnSociety-B.Russell/ (last access: 30 March 2021), 1952.

Sagoff, M.: Welcome to the Narcisscene, Breakthrough Journal, 9, available at: https://thebreakthrough.org/journal/no. -9-summer-2018/welcome-to-the-narcisscene (last access: 30 March 2021), 2018.

Sanders, G.: An Aristotelian approach to quantum mechanics, Academia, available at: http://www.academia.edu/35229710/ An_Aristotelian_Approach_to_Quantum_Mechanics (last access: 30 March 2021), 2018.

Schmidt, W.: Heronis Alexandrini Opera quae supersunt omnia, vol. I, Pneumatica et automata, Aedibus B.G. Teubneri, Stutgardiae, 596 pp. available at: https://archive.org/details/ heronsvonalexandhero (last access: 30 March 2021), 1899 (in Greek with translation in Latin).

Thevet, A.: Les Vrais Pourtraits et Vies Des Hommes Illustres Grecz, Latins Et Payens, I. Kervert et Guillaume Chaudière, Paris, 392 pp., available at: https://archive.org/details/ lesvraispourtrai01thev (last access: 30 March 2021), 1584.

Taylor, A. E.: Aristotle, T.C. \& E.C. Jack, London, available at: http://www.gutenberg.org/files/48002/48002-h/48002-h.html (last access: 27 March 2021), 1919.

Todd, D. and Mays, L.: Groundwater Hydrology, John Wiley \& Sons, Hoboken, NJ, USA, 2005.

Tropp, H. S.: The origins and history of the Fields medal, Historia Mathematica, 3, 167-181, 1976.

UNESCO (United Nations Educational, Scientific and Cultural Organization): Report, Preparatory Meeting on the Long-Term Programme of Research in Scientific Hydrology, UNESCO House, 
Paris, UNESCO/NS/181, available at: http://unesdoc.unesco. org/images/0001/000173/017325EB.pdf (last access: 30 March 2021), 1963.

UNESCO (United Nations Educational, Scientific and Cultural Organization): Final Report, International Hydrological Decade, Intergovernmental Meeting of Experts, UNESCO House, Paris, UNESCO/NS/188, available at: http://unesdoc. unesco.org/images/0001/000170/017099EB.pdf (last access: 30 March 2021), 1964

US Ad Hoc Panel on Hydrology: Scientific Hydrology, U.S. Federal Council for Science and Technology, Washington, DC., 37 pp., 1962.

Vardi, I.: Archimedes, The Sand Reckoner, Preprint, available at: http://www.chronomaitre.org/sand_reckoner.pdf (last access: 30 March 2021), 1997.

Visconti, E. Q.: Planches de l'Iconographie Grecque. De l'Imprimerie de P. Didot l'Ainé, Paris, 58 plates (engravings), available at: https://archive.org/details/gri_33125010850713/, https://arachne.dainst.org/entity/1884649 (last access: 30 March 2021), 1817.
Visconti, E. Q.: Iconographie Grecque (ou Recueil des Portraits Authentiques des Empereurs, Rois, et Hommes Illustres de l'Antiquité), vol. 1-III, J. P. Giegler, Milan, available at: https://zenon.dainst.org/Author/Home?author=Visconti\%2C+ Ennio+Quirino\%2C+1751-1818 (last access: 30 March 2021), 1824-1826.

Wallis, E.: Illustrerad Verldshistoria, Svenska Amerikanaren, Chicago, 1080 pp., available at: https://archive.org/details/ illustreradverld12wall/ (last access: 30 March 2021), 1894.

Wendland, W. M., Scheidegger, A. E., Herschy, R. W., Brassington, F. C., Back, W., Hordon, R. M., Bishop, G. D., Church, M. R., Marsh, T. J., and Herschy, R. W.: Hydrologists (600 bs-ad 1900, edited by: Herschy, R. W. and Fairbridge, R. W., Encyclopedia of Hydrology and Water Resources, Encyclopedia of Earth Science, Springer, Dordrecht, 1998.

Woodcroft, B.: The Pneumatics of Hero of Alexandria, Taylor Walton and Maberly, London, available at: https://archive. org/details/pneumaticsofhero0000hero/ (last access: 30 March 2021), 1851. 